\title{
Some Applications of a Novel Desirability Function in Simultaneous Optimization of Multiple Responses
}

\author{
Velibor Marinković \\ Full Professo \\ University of Niš \\ Faculty of Mechanical Engineering
}

In the framework of multi-response optimization techniques, the optimization methodology based on the desirability function is one of the most popular and most frequently used methodologies by researchers and practitioners in engineering, chemistry, technology and many other fields of science and technique. Numerous desirability functions have been introduced to improve the performance of this optimization methodology. Recently, a novel desirability function for multi-response optimization is proposed, which is smooth, nonlinear, and differentiable, and thus more suitable for applying some of the more efficient gradient-based optimization methods. This paper evaluates the performance of the proposed method through six real examples. After a comparative analysis of the results, it is shown that the proposed method in a certain measure outperforms the other competitive optimization methods.

Keywords: desirability function, multi-response optimization, design of experiments

\section{INTRODUCTION}

In general, there are two categories of optimization techniques. The first deals with single optimization problems, while the second solves multi-response optimization (MRO) problems.

However, in practice, each product/process/system consists of many quality characteristics (responses) that need to be optimized. In such circumstances, it is not reasonable to optimize each response separately, since an improvement in one response, as a rule, degrades at least one or several of the remaining responses.

Therefore, in real world problems, MRO involve the simultaneous optimization of many different and often conflicting responses. In such problems, there is no unique optimal solution, but rather a set of alternative solutions.

There are many different MRO optimization techniques, but most of them are very complex and sophisticated [1-5]. Therefore, researchers and practitioners have a lot of difficulty in selecting the appropriate technique for a specific problem at hand.

Desirability function methodology is an easy-to-use and well-established approach and, as such, quite acceptable to many researchers and practitioners.

The desirability function-based optimization approach combines desirability function (DF) and design of experiments (DOE). The application of this methodology is not limited to specific optimization problems; on the contrary, it is one of the most widely used methodologies in many fields of science, research and development [5-8].

Received: March 2021, Accepted: April 2021

Correspondence to: Dr Velibor Marinković

Faculty of Mechanical Engineering,

Aleksandra Medvedeva 14, 18000 Niš, Serbia

E-mail: velmar@masfak.ni.ac.rs

doi:10.5937/fme2103534M

(C) Faculty of Mechanical Engineering, Belgrade. All rights reserved
It is commonly known that there is no efficient general-purpose universal optimization method. Among the many optimization techniques presented for desirability functions that can be employed to solve MRO problems, the direct search (DS) method and its modifications are still the "first resort methods" [9], and sometimes the only options for solving a large class of optimization problems.

In many cases the DS algorithms can provide acceptable approximation solutions, but it has the propensity to fall into the trap of a local optimum (i.e. it is prone to converge to a non-stationary point), so it is necessary that the algorithm is starting in multiple initial points into the feasible space in an attempt to find the best (global) optimum. However, in the desirability function methodology such a danger is not large, since the subregion of interest for optimization is relatively narrow, certainly less than the experimental region considered. Some of the DS methods (e.g. Nelder-Mead simplex method) are very popular nowadays within the research and scientific community because they are simple, flexible, easy to understand and relatively easy to implement.

Commercially available software products usually do optimization of desirability functions by derivate free search methods, or gradient-based methods.

It is necessary to note that some alternatives to desirability function-based approach have been developed, such as gray rational analysis, physical progra-mming, vectorial optimization, quality loss function approach, principal component analysis, process capa-bility index-based aproach, and their hybrid variants [9-13].

In recent years, considerable attention has been paid by researchers and practitioners towards employing some successful metaheuristic search techniques for global optimization, such as genetic algorithm (GA), simulated annealing (SA) algorithm, particle swarm optimization (PSO) algorithm , ant colony optimization 
(ACO) algorithm, tabu search (TS) algorithm, artificial bee colony $(\mathrm{ABC})$ algorithm, differential evolution (DE), including the later developed cuckoo search (CS) algorithm, imperialist competitive algorithm (ICA) teaching-learning-based optimization (TLBO) method, gray wolf optimizer (GWO), and many others, which can provide the best feasible solution of an optimization problem [14-20]. At the present time, among these algorithms, the classical genetic algorithm and its hybrid variants are still the most popular techniques for various optimization problems [15], [21], especially in material processing technologies [16], [22], [23]. Many of the above mentioned algorithms are used for single and/or multi-response optimization.

In some multi-response optimization problems, the graphical approach can be very useful when two design factors (input variables) are considered and the number of responses (output variables) is not too large. In such cases, the contour plot methodology allows to find visually the optimal conditions that simultaneously satisfy all the involved responses. For three design factors, utilizing a large number of successful iterations, the near-optimal solution can be found. When the number of design factors is greater than three, the graphical approach becomes impractical.

The remainder of this paper is organized as follows. In the second Section is presented a novel desirability function in detail. In the third section, the optimization procedure is formulated. To verify the proposed approach, six examples are considered in the fourth Section. In the fifth Section different optimization results are compared and discussed. Finally, brief concluding remarks are given in the sixth Section.

\section{DESIRABILITY FUNCTION}

Obviously, any type of free-form transformation (exponential, power, logarithmic, logistic) may be employed as a desirability function [5, 24-29].

Hitherto, many desirability functions have been introduced to improve the performance of the desirability-based optimization method.

Recently, a novel desirability function for multiresponse optimization was recommended [29], which is a smooth, nonlinear, and differentiable function at target points. This desirability function was defined as:

$$
d_{j}\left(\psi_{j}\right)=\left\{\begin{array}{lc}
\left(1-\psi_{j}^{2}\right)^{r_{j}}, & \text { if }-1 \leq \psi_{j} \leq 1 \\
0, & \text { otherwise }
\end{array} ; d_{j} \in[0,1]\right.
$$

where $\psi_{j}=f\left(\hat{y}_{j}(\mathbf{x})\right)$ is the dimensionless converting function, which linearly converts the predicted (fitted) responses into coded variables $j=(1,2, \ldots ., m), \hat{y}_{j}(\mathbf{x})$ is the $j$ th estimated response function, $\mathbf{x}$ is the vector of the coded input variables $\left(x \in R^{n}\right), r_{j}$ is the shape parameter $\left(r_{j}>0\right)$.

The individual desirability functions are defined according to the nature of the responses to be optimized, which are usually classified in three main categories:

1. The nominal-the-best (NTB);
2. The larger-the-better (LTB);

3. The smaller-the-better (STB).

Note: For the one-sided desirability function $r_{j}=r_{j}^{s}$ (LTB) or $r_{j}=r_{j}^{t}$ (STB), and for the two-sided symmetrical desirability function (NTB) $r_{j}=r_{j}^{s}=r_{j}^{t}$.

A graphical representation of these functions is given in Figure 1.
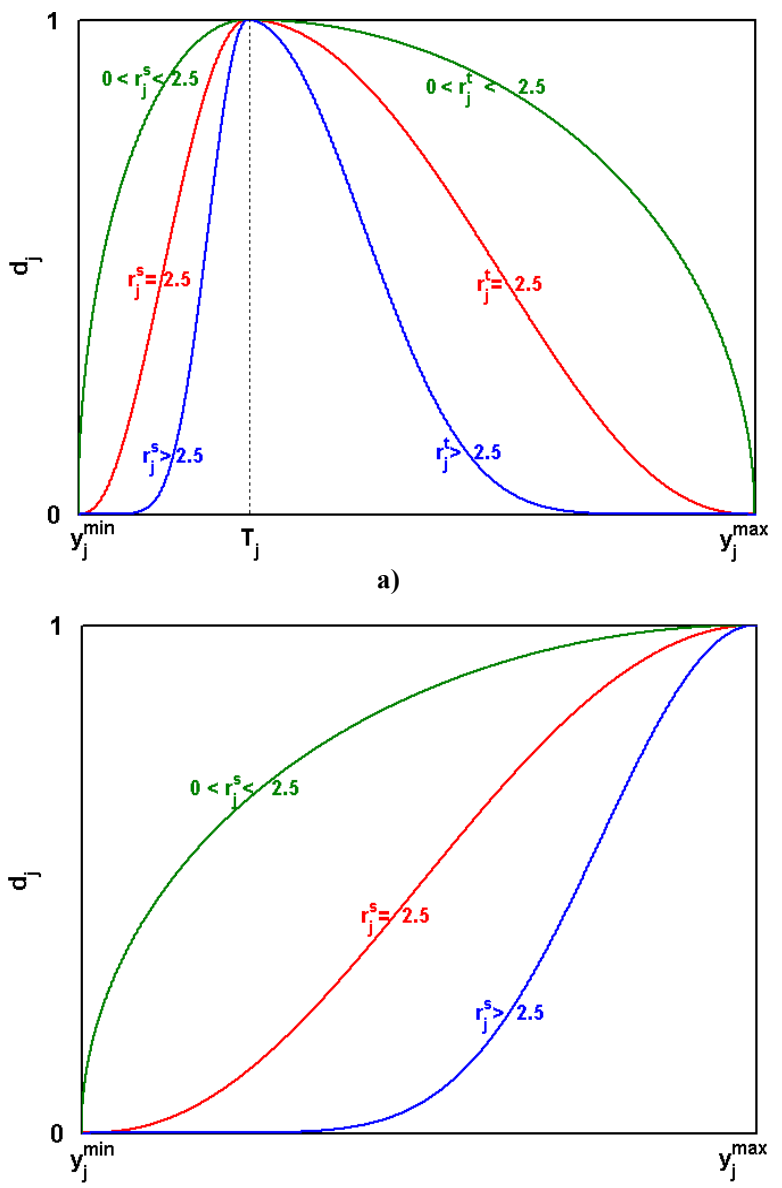

b)

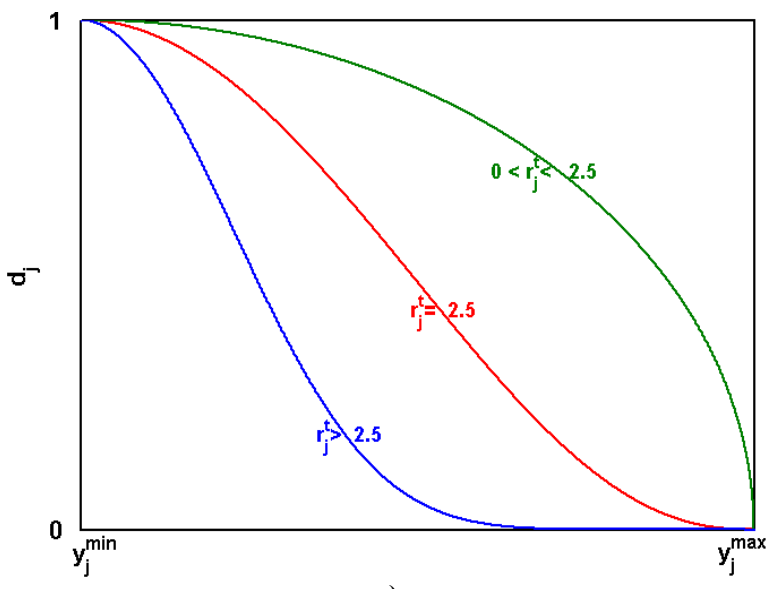

c)

Figure 1. Graphical representation of desirability function: a) NTB, b) LTB, c) STB

Depending on whether a particular response has to be minimized, maximized or assigned to a certain target value, the desirability function from equation (1) can be expressed as follows:

- for the NTB type response, 


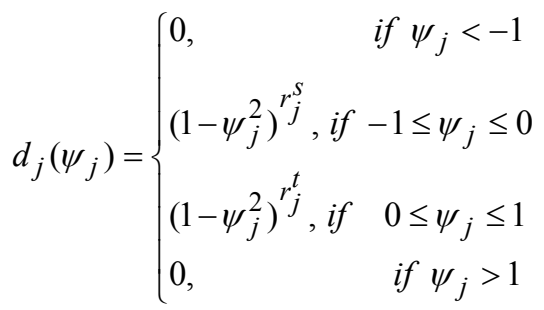

with,

$$
\psi_{j}\left(\hat{y}_{j}(\mathbf{x})\right)=\left\{\begin{array}{l}
\frac{\hat{y}_{j}(\mathbf{x})-T_{j}}{T_{j}-y_{j}^{\min }}, \text { if } y_{j}^{\min } \leq \hat{y}_{j}(\mathbf{x}) \leq T_{j} \\
\frac{\hat{y}_{j}(\mathbf{x})-T_{j}}{y_{j}^{\max }-T_{j}}, \text { if } T_{j} \leq \hat{y}_{j}(\mathbf{x}) \leq y_{j}^{\max }
\end{array}\right.
$$

- for the LTB type response,

$$
d_{j}\left(\psi_{j}\right)=\left\{\begin{array}{lr}
0, & \text { if } \psi_{j}<-1 \\
\left(1-\psi_{j}^{2}\right)^{r_{j}^{s}}, & \text { if }-1 \leq \psi_{j} \leq 0 \\
1, & \text { if } \psi_{j}>0
\end{array}\right.
$$

with,

$$
\psi_{j}\left(\hat{y}_{j}(\mathbf{x})\right)=\frac{\hat{y}_{j}(\mathbf{x})-y_{j}^{\max }}{y_{j}^{\max }-y_{j}^{\min }}, \text { if } y_{j}^{\min } \leq \hat{y}_{j}(\mathbf{x}) \leq y_{j}^{\max }
$$

- for the STB type response,

$$
d_{j}\left(\psi_{j}\right)=\left\{\begin{array}{lr}
1, & \text { if } \psi_{j}<0 \\
\left(1-\psi_{j}^{2}\right)^{r_{j}^{t}}, & \text { if } 0 \leq \psi_{j} \leq 1 \\
0, & \text { if } \psi_{j}>1
\end{array}\right.
$$

with,

$$
\psi_{j}\left(\hat{y}_{j}(\mathbf{x})\right)=\frac{\hat{y}_{j}(\mathbf{x})-y_{j}^{\min }}{y_{j}^{\max }-y_{j}^{\min }}, \quad \text { if } y_{j}^{\min } \leq \hat{y}_{j}(\mathbf{x}) \leq y_{j}^{\max }
$$

where $y_{j}^{\min }$ and $y_{j}^{\max }$ are the lower and the upper bound (specification limits) on the $j$ th response, respectively, $r_{j}^{s}$ and $r_{j}^{t}$ are the $j$ th adjustable shape parameters, and $T_{j}$ is the target value of the $j$ th response which is a NTB- type one.

For some reason, the decision maker (DM) may decide that a response has to be "in range". In such a case, the individual desirability function is the simplest, namely $d_{j} \equiv 1$ for $\mathrm{y}_{\mathrm{j}}^{\min } \leq \hat{\mathrm{y}}_{\mathrm{j}}(\mathbf{x}) \leq \mathrm{y}_{\mathrm{j}}^{\max }$ (otherwise, $\left.d_{j} \equiv 0\right)$.

The upper bound $y_{j}^{\max }$ denotes a large enough value for the LTB type response, whereas the lower bound $y_{j}^{\min }$ denotes a small enough value for the STB type response. In other words, these bounds are target values for LTB- and STB-type responses. If $r_{j}^{s}$ or $r_{j}^{t}$ increases, the desirability function becomes more convex with more emphasis to the target; on the contrary, if $r_{j}^{s}$ or $r_{j}^{t}$ decreases, the desirability function becomes more concave with less emphasis to the target.

In general, in both the one-sided desirability functions (STB or LTB) and the two-sided desirability function (NTB) is $r_{j}^{s} \neq r_{j}^{t}$.

\subsection{Determination of bounds}

The bounds of design factors $x_{i}$ are defined when selecting the experimental matrix, so they are known during the optimization process.

The bounds (and targets) of each response $\mathrm{y}_{\mathrm{j}}(\mathbf{x})$ should be determined in advance to define individual desirability functions. These bounds may be chosen arbitrarily in a different way, for instance, on the basis of product/process operating limits, the decision maker's subjective choice, consensus of experts, etc.

Instead of using the preference information about responses a priori (or in absence of such information), the physical range of individual response can be used to determine bounds as follows:

$$
\begin{aligned}
& y_{j}^{\min } \approx \min \left(\hat{y}_{j}(\mathbf{x})\right), j=1,2,3, \ldots, m \\
& y_{j}^{\max } \approx \max \left(\hat{y}_{j}(\mathbf{x})\right)
\end{aligned}
$$

The bounds determined by equations (5) and (6) can represent the extreme values of the estimated (or experimental) responses within the entire investigated space $\Omega$.

In that case, after the calculation phase, the DM will decide whether the current solution with the adopted bounds is satisfactory or not [30].

\subsection{Determination of shape parameters}

The shape parameters in desirability functions $r_{j}^{s}$ and/or $r_{j}^{t}$ can be chosen arbitrarily as described in previous chapter for the bounds. However, these parameters can be determined in a less arbitrary manner.

Namely, the individual desirability function is completely defined by just one point on the desirability curve (see Figure1). That point, say $a_{0}\left\{\psi_{j, 0}, d_{j, 0}\right\}$ represents the critical value of a response and its corresponding degree of desirability (satisfaction).

The unknown shape parameter is computed easily from the equation:

$$
r_{j}=\frac{\ln d_{j, 0}}{\ln \left(1-\psi_{j, 0}^{2}\right)}
$$

A researcher or a group of experts may choose any desirable value for each involved response, assign to it an adequate desirability, and then apply equation (7).

Table 1 shows a simplified desirability scale with qualitative (linguistic) interpretation of desirability values, according to Harrington and other researchers $[7,27,31]$.

The rule is simple; a high value of the response (close to the target value) corresponds to a high value of 
desirability, and vice versa. In this way, it is most likely that a different shape parameter for each individual desirability function will be obtained.

Table 1. Desirability scale

\begin{tabular}{cll}
\hline $\mathrm{d}$ & \multicolumn{2}{c}{ Qualitative interpretation } \\
\hline $1.0-0.8$ & very high & fully acceptable (excellent) \\
$0.8-0.6$ & high & acceptable \\
$0.6-0.4$ & middle & satisfactory \\
$0.4-0.2$ & low & acceptable/unacceptable \\
$0.2-0.0$ & very low & completely unacceptable \\
\hline
\end{tabular}

Certainly, the shape parameter must be chosen carefully, since its different values produce different forms of desirability curve as can be seen from Figure 1 .

For instance, large shape parameters $\left(r_{j}>2.5\right)$ indicate that only response values near its target value provide a specified high desirability, while small shape parameters $\left(r_{j}<2.5\right)$ provide high desirability in a wide range of response values around the target value.

In that sense, a shape parameter $r_{j}=2.5$ can be accepted as the "default" shape parameter.

\subsection{Overall desirability}

Harrington [27] defined an average desirability, called composite or overall desirability, as the geometric mean of the individual desirability functions:

$$
D(\mathbf{y})=\left[\prod_{j=1}^{m} d_{j}\left(y_{j}\right)\right]^{\frac{1}{m}}
$$

where $m$ is the number of responses.

Using this aggregated function, the multiple quality characteristics are converted into an equivalent singlequality characteristic, which is to be optimized. On the other hand, it should be taken into account that the overall desirability is a complex, nonlinear, and sometimes, multimodal function (because of curvature in the response surfaces and their combination into the desirability function).

Obviously, the overall desirability also ranges between zero and one. If any individual desirability $d_{j}$ of the corresponding response $\hat{y}_{j}$ becomes zero, then the overall desirability $D$ also becomes zero, independently of the values of the remaining individual desirability functions.

For the product or process development it means that if only one of several quality characteristics is outside of the specified limits, the considered process or product is unacceptable to users ("all or nothing").

Principally, the higher value of $D$, the better compromise exists among the multiple responses.

In real circumstances, it is quite likely that there is a difference in the importance levels (priorities) of different responses, i.e. that one response has a greater impact on the product or process in comparison with the others.

For that reason, Derringer and Suich [28] proposed an extended overall desirability as the weighted geometric mean of the individual desirability functions:

$$
D(\mathbf{y})=\left[\prod_{j=1}^{m} d_{j}\left(y_{j}\right)^{w_{j}}\right]^{\frac{1}{\sum w_{j}}}
$$

where $w_{j}$ is the user-specified weight of the $j$-th predicted response.

If all the weights are the same, equation (9) is reduced to equation (8). This suggests that both functions have similar characteristics. Usually, the exponents of the individual desirability functions in the equation (9) are given in the normalized form, which satisfies the conditions $\sum w_{j}=1$ and $w_{j} \in(0,1)$.

Equation (9) should be used when at least one response is of greater importance than the others. The weights can be specified by the DM next to the shape parameters in the desirability functions. In doing so, the DM must take into account the relative importance of the responses with respect to each other.

\section{MULTI-RESPONSE OPTIMIZATION PROCEDURE}

As noted above, using this methodology, the complicated multiple optimization problem is transformed into a simplified single optimization problem. In such a case, the aim of optimization procedure is to find the optimal vector of design factors $\mathbf{x}^{*}$ which maximize the overall desirability $D$.

There are many numerical techniques that can be used to solve this nonlinear constrained optimization problem. Sometimes these techniques are referred to as nonlinear programming methods.

In this case, the standard nonlinear constrained optimization procedure can be formally expressed as follows:

$$
\begin{array}{ll}
\text { Maximize, } & D\{\mathbf{y}(\mathbf{x})\} \\
\text { subject to: } & y_{j}^{L} \leq y_{j}(\mathbf{x}) \leq y_{j}^{U}(j=1,2, \ldots ., m) \\
& x_{i}^{L} \leq x_{i} \leq x_{i}^{U} \quad(i=1,2, \ldots ., n)
\end{array}
$$

where the superscripts $L$ and $U$ denote the lower and upper bounds of the functions $y_{j}(\mathbf{x})$ and variables $x_{i}$, respectively.

The constraints $y_{j}(\mathbf{x})$ in equation (10) can be linear or nonlinear functions, and, as a rule, they are given in explicit form. In the general case, these constraints can be one-sided or two-sided constraints.

According to the priority-based approach, instead of overall desirability, the most important response (primary response) is used as the objective function and the rest of $(m-1)$ responses (secondary responses) are considered as inequality constraints.

This is an essential different concept from the desirability function methodology. Certainly, this approach offers less chance of achieving a good compromise among the predicted responses.

\section{ILLUSTRATIVE EXAMPLES}

The applicability, efficiency and accuracy of the proposed method will be demonstrated on six examples that have been widely studied in the literature $[28,30$, 32-43]. 


\subsection{Example 1}

Firstly, the famous 'tire tread compound problem', originally discussed by Derringer and Suich [28], will be presented. In this example the tire tread performance were characterized via four responses (output variables).

These responses are PICO abrasion index $\left(y_{1}\right), 200 \%$ modulus $\left(y_{2}\right)$, elongation at break $\left(y_{3}\right)$, and hardness $\left(y_{4}\right)$. As process factors (input variables) three chemical ingredients were selected, namely, hydrated silica $\left(x_{1}\right)$, silane coupling agent $\left(x_{2}\right)$, and sulfur $\left(x_{3}\right)$.

The central composite design (with six center points and six star points) was employed for experimentation. The cubical experimental region $\Omega$ was given as $-1.633 \leq x_{i} \leq 1.633(i=1,2,3)$. All the data are shown in Table 2 .

Table 2. Design matrix and experimental results

\begin{tabular}{ccccccc}
\hline \multicolumn{3}{c}{ Coded design factors } & \multicolumn{4}{c}{ Responses } \\
$x_{1}$ & $x_{2}$ & $x_{3}$ & $y_{1}$ & $y_{2}$ & $y_{3}$ & $y_{4}$ \\
\hline-1 & -1 & 1 & 102 & 900 & 470 & 67.5 \\
1 & -1 & -1 & 120 & 860 & 410 & 65.0 \\
-1 & 1 & -1 & 117 & 800 & 570 & 77.5 \\
1 & 1 & 1 & 198 & 2294 & 240 & 74.5 \\
-1 & -1 & -1 & 103 & 490 & 640 & 62.5 \\
1 & -1 & 1 & 132 & 1289 & 270 & 67.0 \\
-1 & 1 & 1 & 132 & 1270 & 410 & 78.0 \\
1 & 1 & -1 & 139 & 1090 & 380 & 70.0 \\
-1.633 & 0 & 0 & 102 & 770 & 590 & 76.0 \\
1.633 & 0 & 0 & 154 & 1690 & 260 & 70.0 \\
0 & -1.633 & 0 & 96 & 700 & 520 & 63.0 \\
0 & 1.633 & 0 & 163 & 1540 & 380 & 75.0 \\
0 & 0 & -1.633 & 116 & 2184 & 520 & 65.0 \\
0 & 0 & 1.633 & 153 & 1784 & 290 & 71.0 \\
0 & 0 & 0 & 133 & 1300 & 380 & 70.0 \\
0 & 0 & 0 & 133 & 1300 & 380 & 68.5 \\
0 & 0 & 0 & 140 & 1145 & 430 & 68.0 \\
0 & 0 & 0 & 142 & 1090 & 430 & 68.0 \\
0 & 0 & 0 & 145 & 1260 & 390 & 69.0 \\
0 & 0 & 0 & 142 & 1344 & 390 & 70.0 \\
\hline & & & & & & \\
& 0 & 0 & 0 & & & 0
\end{tabular}

For each response the same experimental region was employed to fit the full second-order regression model as follows:

$$
\begin{aligned}
& \hat{y}_{1}(\mathbf{x})=139.12+16.49 x_{1}+17.88 x_{2}+10.91 x_{3}-4.01 x_{1}^{2}- \\
& 3.45 x_{2}^{2}-1.57 x_{3}^{2}+5.13 x_{1} x_{2}+7.13 x_{1} x_{3}+7.88 x_{2} x_{3} \\
& \hat{y}_{2}(\mathbf{x})=1261.11+268.15 x_{1}+246.50 x_{2}+139.48 x_{3} \\
& -83.55 x_{1}^{2}-124.79 x_{2}^{2}+199.17 x_{3}^{2}+69.38 x_{1} x_{2}+ \\
& 94.13 x_{1} x_{3}+104.37 x_{2} x_{3} \\
& \hat{y}_{3}(\mathbf{x})=400.38-99.67 x_{1}-31.40 x_{2}-73.92 x_{3}+ \\
& 7.93 x_{1}^{2}+17.31 x_{2}^{2}+0.43 x_{3}^{2}+8.75 x_{1} x_{2}+6.25 x_{1} x_{3}+ \\
& 1.25 x_{2} x_{3}
\end{aligned}
$$$$
\hat{y} 4(\mathbf{x})=68.91-1.41 x_{1}+4.32 x_{2}+1.63 x_{3}+1.56 x_{1}^{2}+
$$$$
0.06 x_{2}^{2}-0.32 x_{3}^{2}-1.63 x_{1} x_{2}+0.13 x_{1} x_{3}-0.25 x_{2} x_{3}
$$

Whenever there is no significant difference between a full and incomplete mathematical model, the full model should be selected. In any case, a polynomial of higher degree (such as a second-order model) is a reasonable approximation of the true response surface over the relatively small (feasible) region of the design factors (which is a typical case in the optimization methodology applying the desirability function). In any case, polynomial models are often preferable, because these models are much easier to fit and work with than complicated nonlinear models.

Based on the decision maker's preference information, the following limitations for each response are given, as follows:

$$
\begin{aligned}
& y_{1}>120, \\
& y_{2}>1000, \\
& 400<y_{3}<600, \\
& 60<y_{4}<75 .
\end{aligned}
$$

In the investigated experimental space $\Omega$, this inequalities define nonempty feasible region $\Omega^{\prime}\left(\Omega^{\prime} \subset \Omega\right)$.

Instead the preference requirements, the bounds of the four responses $\left(y_{j}^{\min }, y_{j}^{\max }\right)$ were adopted based on the physical ranges (according the aforementioned concept), this is, $(90,190)$ for $y_{1},(1000,1500)$ for $y_{2}$, $(350,650)$ for $y_{3}$, and $(60,75)$ for $y_{4}$.

Note: If no explicit specifications from the DM are available in advance, then this (no-preference) approach remains the only starting option.

The same shape parameters were selected for each of the individual desirability functions $r_{j}^{s}=r_{j}^{t}=2.5$.

Following the conditions and limitations adopted previously, the optimization procedure was carried out. After optimization procedure, the initial solution at the optimal point $\mathbf{x}^{*}=\left\{x_{1}^{*}, x_{2}^{*}, x_{3}^{*}\right\}=\{0.126,0.406,-1.241\}$, with the corresponding estimated response values $\hat{\mathbf{y}}^{*}=$ $\left\{y_{1}^{*}(\mathbf{x}), y_{2}^{*}(\mathbf{x}), y_{3}^{*}(\mathbf{x}), y_{4}^{*}(\mathbf{x})\right\}=\{127.1, \quad 1443.0, \quad 469.3$, $68.0\}$, and the overall desirability $D^{*}=0.702$ was found.

All the estimated response values satisfy inequalities (11).

Sometimes the solution obtained by applying the procedure described above does not meet the desired specifications. On the other hand, regardless of the satisfactory solution, the DM may require a better and more reliable solution. In such a case, the problem can be resolved using the shape-based and/or bound-based interactive desirability function method proposed by Jeong and $\operatorname{Kim}[26,30]$.

By using this method the researchers attempt to find the most favorable compromise solution (the best one) in a small number of iterations. However, if the number and magnitude of preference parameters and their combinations that must be specified are large, then the number of iterations may be very large. Because it is actually a trial-and-error procedure, it is not easy for $\mathrm{DM}$ to find the most appropriate solution. In practice, the DM usually relies only on a free assessment, own intuition and some known solutions from the literature.

The simplest way to change the shape of individual desirability functions is to vary the shape parameters. In this paper, a systematic method for determining the shape parameter values in the individual desirability functions will be presented. 
This procedure is based on a simulated experiment and response surface methodology (RSM) [44], and in this paper will be demonstrated on the Example 1.

For further analysis (to maintain consistency in the comparison of competitive methods), the original bounds and targets of each response were accepted.

Table 3 shows the design matrix and computing results for the simulated experiment (see Appendix). In this experiment the design factors are the shape parameters $r_{1}, r_{2}, r_{3}$, and $r_{4}\left(0.5 \leq r_{k} \leq 10\right)$, and the response is the overall desirability $D_{r}$.

The data collected in Table 3 were employed for fitting the pure quadratic regression model (with original design factors) of the form:

$$
\begin{aligned}
& y=0.9602-0.1616 r_{1}+0.01 r_{2}-0.0334 r_{3}+ \\
& 0.0049 r_{4}+0.0087 r_{1}^{2}-0.0002 r_{2}^{2}+0.0018 r_{3}^{2} \\
& -0.0005 r_{4}^{2}
\end{aligned}
$$

The optimization task is to find the point, in which the response (overall desirability) attains the maximum.

The optimal solution was found at the point $r^{*}=\left\{r_{1}^{*}, r_{2}^{*}, r_{3}^{*}, r_{4}^{*}\right\}=\{0.5,10.0,0.5,4.9\}$, with response

\begin{tabular}{|c|c|c|c|c|}
\hline \multicolumn{4}{|c|}{ Coded (Original) factors } & Response \\
\hline$A\left(r_{l}\right)$ & $B\left(r_{2}\right)$ & $C\left(r_{3}\right)$ & $D\left(r_{4}\right)$ & $y=D_{r}$ \\
\hline $1(0.5)$ & $1(0.5)$ & $1(0.5)$ & $1(0.5)$ & 0.87258 \\
\hline $1(0.5)$ & $2(5.25)$ & $2(5.25)$ & $2(5.25)$ & 0.81508 \\
\hline $1(0.5)$ & $3(10)$ & $3(10)$ & $3(10)$ & 0.80757 \\
\hline $2(5.25)$ & $1(0.5)$ & $2(5.25)$ & $3(10)$ & 0.22572 \\
\hline $2(5.25)$ & $2(5.25)$ & $3(10)$ & $1(0.5)$ & 0.24913 \\
\hline $2(5.25)$ & $3(10)$ & $1(0.5)$ & $2(5.25)$ & 0.42725 \\
\hline $3(10)$ & $1(0.5)$ & $3(10)$ & $2(5.25)$ & 0.07515 \\
\hline $3(10)$ & $2(5.25)$ & $1(0.5)$ & $3(10)$ & 0.23734 \\
\hline $3(10)$ & $3(10)$ & $2(5.25)$ & $1(0.5)$ & 0.17013 \\
\hline
\end{tabular}
$y^{*} \equiv D_{r}^{*}=0.957$.

Table 3. Taguchi $L_{9}\left(3^{4}\right)$ orthogonal array with response

For the new shape parameters, after repeated computing procedure, the new optimal setting $\mathbf{x}^{*}=$ $\{0.020,0.116,-0.806\}$, with the corresponding estimated responses $\hat{\mathbf{y}}^{*}=\{130.8,1299.2,454.6,67.9\}$, and the overall desirability $D^{*}=0.860$ were obtained.



Figure 2. Overlaid contour plot for three design factors and four response constraints with $\times 3$ : sulfur at optimal level
It can be said that the new solution gives a better balanced relationship between the responses.

For this improved solution, Figure 2 shows the contour plot for four responses with a (shaded) feasible region and contour lines of constant overall desirability around the optimum point.

This graphic representation may be helpful for better understanding of the situation.

\subsection{Example 2}

This example, which was originally discussed by Del Castillo et al. [32], refers to a wire-bonding process in the semiconductor industry.

The manufacturer must put together a module in a pre-molded package by bonding wires between the leads (position A) and the silicon chips (position B).

The design (control) factors that influence the temperature at the wire bond are the $\mathrm{N} 2$ flow rate $\left(x_{1}\right)$, the N2 temperature $\left(x_{2}\right)$, and the heater block temperature $\left(x_{3}\right)$.

First three responses are maximum temperature $\left(y_{1}\right)$, beginning bond temperature $\left(y_{2}\right)$, and finish bond temperature $\left(y_{3}\right)$ - at position A. Three other responses are maximum temperature $\left(y_{4}\right)$, beginning bond temperature $\left(y_{5}\right)$, and finish bond temperature $\left(y_{6}\right)$ - at position B.

For more details, readers are referring to the original paper [32].

The design factors and their chosen levels used in the experiment are listed in Table 4. The bounds of design factors define the region of exploration.

Table 4. Factors and their levels

\begin{tabular}{cccccc}
\hline \multicolumn{2}{c}{ Design factors } & Units & $\begin{array}{c}\text { Lower } \\
(-1)\end{array}$ & $\begin{array}{c}\text { Middle } \\
(0)\end{array}$ & $\begin{array}{c}\text { Upper } \\
(+1)\end{array}$ \\
\hline$x_{1}$ & Flow rate & SCFM & 40 & 80.0 & 120 \\
$x_{2}$ & Flow & ${ }^{\circ} \mathrm{C}$ & 200 & 325 & 450 \\
& temper. & & & & \\
$x_{3}$ & $\begin{array}{c}\text { Block } \\
\text { temper. }\end{array}$ & ${ }^{\circ} \mathrm{C}$ & 150 & 250 & 350 \\
\hline
\end{tabular}

The design used to collect the experimental data was a non-composite Box-Behnken design (BBD) with three replicated runs at the center point, for all six responses. The data are summarized in Table 5.

Table 5. Design matrix (BBD) and experimental results

\begin{tabular}{ccccccccc}
\hline \multicolumn{1}{c}{ Coded factors } & \multicolumn{7}{c}{ Responses } \\
\hline$x_{I}$ & $x_{2}$ & $x_{3}$ & $y_{1}$ & $y_{2}$ & $y_{3}$ & $y_{4}$ & $y_{5}$ & $y_{6}$ \\
\hline-1 & -1 & 0 & 139 & 103 & 110 & 110 & 113 & 126 \\
1 & -1 & 0 & 140 & 125 & 126 & 117 & 114 & 131 \\
-1 & 1 & 0 & 184 & 151 & 133 & 147 & 140 & 147 \\
1 & 1 & 0 & 210 & 176 & 169 & 199 & 169 & 171 \\
-1 & 0 & -1 & 182 & 130 & 122 & 134 & 118 & 115 \\
1 & 0 & -1 & 170 & 130 & 122 & 134 & 118 & 115 \\
-1 & 0 & 1 & 175 & 151 & 153 & 143 & 146 & 164 \\
1 & 0 & 1 & 180 & 152 & 154 & 152 & 150 & 171 \\
0 & -1 & -1 & 132 & 108 & 103 & 111 & 101 & 101 \\
0 & 1 & -1 & 206 & 143 & 138 & 176 & 141 & 135 \\
0 & -1 & 1 & 183 & 141 & 157 & 131 & 139 & 160 \\
0 & 1 & 1 & 181 & 180 & 184 & 192 & 175 & 190 \\
0 & 0 & 0 & 172 & 135 & 133 & 155 & 138 & 145 \\
0 & 0 & 0 & 190 & 149 & 145 & 161 & 141 & 149 \\
0 & 0 & 0 & 180 & 141 & 139 & 158 & 140 & 148 \\
\hline
\end{tabular}


Table 6 depicts the minimum, maximum, and corresponding target values for the observed responses.

It is interesting to observe that in this case all six responses belong to the NTB-type response. Also, for the given target values for the responses $y_{2}, y_{3}, y_{5}$, and $y_{6}$, the two-sided desirability functions $d_{2}, d_{3}$, $d_{5}$, and $d_{6}$, are the asymmetrical curves. It is observed from Table 6 that the specification limits of all the response variables are tight as compared to experimental response space (given in Table 5).

Table 6. Type of response and their specifications

\begin{tabular}{ccccc}
\hline Responses & Type & $y_{j}^{\min }$ & $T_{j}$ & $y_{j}^{\max }$ \\
\hline$y_{1}$ & NTB & 185 & 190 & 195 \\
$y_{2}$ & NTB & 170 & 185 & 195 \\
$y_{3}$ & NTB & 170 & 185 & 195 \\
$y_{4}$ & NTB & 185 & 190 & 195 \\
$y_{5}$ & NTB & 170 & 185 & 195 \\
$y_{6}$ & NTB & 170 & 185 & 195 \\
\hline
\end{tabular}

Also, the second-order polynomial model was fitted to each of the six responses as follows:

$$
\begin{aligned}
& \hat{y}_{1}(\mathbf{x})=180.67+2.50 x_{1}+23.38 x_{2}+3.63 x_{3}-5.58 x_{1}^{2}- \\
& 6.83 x_{2}^{2}+1.67 x_{3}^{2}+6.25 x_{1} x_{2}+4.25 x_{1} x_{3}-19.00 x_{2} x_{3} \\
& \hat{y}_{2}(\mathbf{x})=141.67+6.00 x_{1}+21.63 x_{2}+14.13 x_{3}-2.58 x_{1}^{2}- \\
& 0.33 x_{2}^{2}+1.67 x_{3}^{2}+0.75 x_{1} x_{2}+0.25 x_{1} x_{3}+1.00 x_{2} x_{3} \\
& \hat{y}_{3}(\mathbf{x})=139.00+6.63 x_{1}+16.00 x_{2}+20.38 x_{3}-6.13 x_{1}^{2}+ \\
& 1.63 x_{2}^{2}+4.88 x_{3}^{2}+5.00 x_{1} x_{2}+0.25 x_{1} x_{3}-2.00 x_{2} x_{3} \\
& \hat{y}_{4}(\mathbf{x})=158.00+8.50 x_{1}+30.63 x_{2}+7.88 x_{3}-13.25 x_{1}^{2}- \\
& 1.50 x_{2}^{2}-4.00 x_{3}^{2}+11.25 x_{1} x_{2}+2.25 x_{1} x_{3}-1.00 x_{2} x_{3} \\
& \hat{y}_{5}(\mathbf{x})=139.67+4.25 x_{1}+19.75 x_{2}+16.50 x_{3}-5.83 x_{1}^{2}+ \\
& 0.17 x_{2}^{2}-0.83 x_{3}^{2}+7.00 x_{1} x_{2}+1.00 x_{1} x_{3}-1.00 x_{2} x_{3} \\
& \hat{y}_{6}(\mathbf{x})=147.33+4.50 x_{1}+15.63 x_{2}+27.38 x_{3}-4.42 x_{1}^{2}+ \\
& 0.83 x_{2}^{2}-1.673+4.75 x_{1} x_{2}+1.75 x_{1} x_{3}-1.00 x_{2} x_{3}
\end{aligned}
$$

The "default" shape parameters were set in this example, for all the individual desirability functions in equations (2). Also, Harrington equation (8) for overall desirability was used.

The objective of multi-response optimization in this example is to make the responses as close as possible to their predefined target values (by maximizing the overall desirability).

After optimization procedure, the optimal solution at the point $\mathbf{x}^{*}=\{0.591,0.794,1.000\}$, with the corresponding estimated response values $\hat{\mathbf{y}}^{*}=\{190.1$, $178.4,180.7,191.5,174.7,189.6\}$, and the overall desirability $D^{*}=0.589$ was found.

All the estimated response values satisfy the requirements defining in Table 6 .

Figure 3 shows the contour plot for six responses and contour lines of constant overall desirability around the optimum point inside the feasible region.
As in Example 1, the same improvement procedure could be repeated for Example 2. Obviously, it is not necessary in this case.

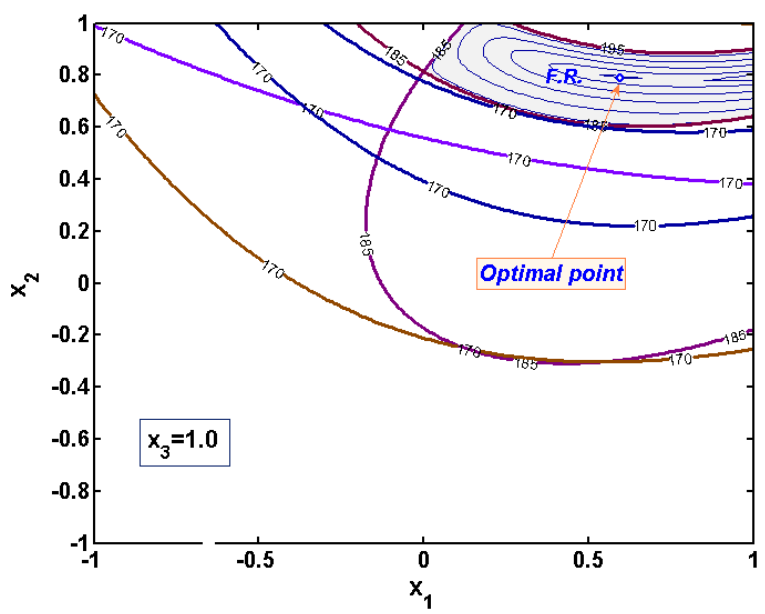

Figure 3. Overlaid contour plot for three design factors and six response constraints with $\times 3$ : the heater block temperature at optimal level (F.R. is the abbreviation for the feasible region)

\subsection{Example 3}

Mangili et al. [37] presented a paper in which they studied and optimized the ultrasonic devulcanization of a ground tire in a co-rotating twin-screw extruder.

In this work a twenty-eight, fully randomized, central composite face-centered design was used to investigate the chosen experimental space.

Table 7 shows the levels for each chosen design factor, including the ultrasonic amplitude $\left(x_{1}\right)$, screw speed $\left(x_{2}\right)$, slow rate $\left(x_{3}\right)$, and temperature $\left(x_{4}\right)$.

The complex viscosity $\left(y_{1}\right)$, cross-link density $\left(y_{2}\right)$, gel fraction $\left(y_{3}\right)$, modulus at $100 \%$ of elongation $\left(y_{4}\right)$, tensile strength $\left(y_{5}\right)$, and elongation at break $\left(y_{6}\right)$ were chosen as responses.

Table 8 depicts the response types as well as bound values for all the observed responses.

Table 7. Factors and their levels

\begin{tabular}{cccccc}
\hline Design factors & Units & \multicolumn{3}{c}{ Factor levels } \\
& & $\begin{array}{c}\text { Lower } \\
(-1)\end{array}$ & $\begin{array}{c}\text { Middle } \\
(0)\end{array}$ & $\begin{array}{c}\text { Upper } \\
(+1)\end{array}$ \\
\hline$x_{1}$ & Amplitude & $\mu \mathrm{m}$ & 5 & 8.5 & 12 \\
$x_{2}$ & Screw speed & $\mathrm{rpm}$ & 150 & 200 & 250 \\
$x_{3}$ & Flow rate & $\mathrm{g} / \mathrm{min}$ & 4 & 6 & 8 \\
$x_{4}$ & Temperature & ${ }^{0} \mathrm{C}$ & 130 & 170 & 210 \\
\hline
\end{tabular}

Table 8. Type of response and their specifications

\begin{tabular}{cccccc}
\hline \multirow{2}{*}{ Response } & Type & $y_{j}^{\min }$ & $y_{j}^{\max }$ & $r_{j}{ }^{\mathrm{a}}$ & $t_{j}{ }^{\mathrm{b}}$ \\
\hline$y_{1}$ & STB & 0.80 & 4.16 & 1 & -1 \\
$y_{2}$ & STB & 0.018 & 0.044 & 1 & -1 \\
$y_{3}$ & STB & 73.8 & 85.3 & 1 & -1 \\
$y_{4}$ & LTB & 2.52 & 3.67 & 3 & -3 \\
$y_{5}$ & LTB & 3.69 & 6.46 & 3 & -3 \\
$y_{6}$ & LTB & 102 & 194 & 1 & -1 \\
\hline
\end{tabular}

${ }^{a}$ Shape factors for Derringer-Suich desirability approach

${ }^{\mathrm{b}}$ Exponents for Kim-Lin desirability approach

Also, in this table are given the corresponding values of the shape factors $\left(r_{j}\right)$ and exponents $\left(t_{j}\right)$ used 
for the two different desirability approaches. The DM has (arbitrarily) assigned larger values of these parameters to the responses $y_{4}$ and $y_{5}$.

The results of this extensive experiment were given in the original paper [37].

A second-order polynomial model was fitted to each of the six responses and then reduced to the best subset model as follows:

$$
\begin{aligned}
& \hat{y}_{1}(\mathbf{x})=2.45-0.74 \mathrm{x}_{1}-0.36 \mathrm{x}_{2}+0.18 \mathrm{x}_{3}-0.36 \mathrm{x}_{4}+ \\
& 0.40 \mathrm{x}_{1}^{2}-0.47 \mathrm{x}_{4}^{2}-0.0000002 \mathrm{x}_{1} \mathrm{x}_{2}+0.21 \mathrm{x}_{1} \mathrm{x}_{4}- \\
& 0.19 \mathrm{x}_{2} \mathrm{x}_{4}+0.15 \mathrm{x}_{1} \mathrm{x}_{2} \mathrm{x}_{4} \\
& \hat{y}_{2}(\mathbf{x})=0.0295-0.0047 \mathrm{x}_{1}-0.0038 \mathrm{x}_{2}+0.0002 \mathrm{x}_{3}- \\
& 0.0037 \mathrm{x}_{4}-0.0004 \mathrm{x}_{1} \mathrm{x}_{2}+0.0009 \mathrm{x}_{1} \mathrm{x}_{3}+0.0021 \mathrm{x}_{1} \mathrm{x}_{4} \\
& -0.0012 \mathrm{x}_{2} \mathrm{x}_{3}+0.0003 \mathrm{x}_{3} \mathrm{x}_{4}+0.0016 \mathrm{x}_{1} \mathrm{x}_{2} \mathrm{x}_{3}- \\
& 0.0012 \mathrm{x}_{1} \mathrm{x}_{3} \mathrm{x}_{4} \\
& \hat{y}_{3}(\mathbf{x})=79.0-3.2 \mathrm{x}_{1}-0.9 \mathrm{x}_{2}+0.4 \mathrm{x}_{3}-0.9 \mathrm{x}_{4}+1.1 \mathrm{x}_{1}^{2}- \\
& 1.1 \mathrm{x}_{3}^{2}+0.02 \mathrm{x}_{1} \mathrm{x}_{2}+0.3 \mathrm{x}_{1} \mathrm{x}_{3}+0.8 \mathrm{x}_{1} \mathrm{x}_{4}-0.4 \mathrm{x}_{2} \mathrm{x}_{3}- \\
& 0.7 \mathrm{x}_{2} \mathrm{x}_{4}+0.4 \mathrm{x}_{1} \mathrm{x}_{2} \mathrm{x}_{3}+0.4 \mathrm{x}_{1} \mathrm{x}_{2} \mathrm{x}_{4} \\
& \hat{y}_{4}(\mathbf{x})=3.05-0.28 \mathrm{x}_{1}-0.03 \mathrm{x}_{2}+0.02 \mathrm{x}_{3}-0.10 \mathrm{x}_{4}+ \\
& 0.13 \mathrm{x}_{1}^{2}-0.22 \mathrm{x}_{3}^{2}-0.01 \mathrm{x}_{1} \mathrm{x}_{2}+0.06 \mathrm{x}_{1} \mathrm{x}_{4}-0.07 \mathrm{x}_{2} \mathrm{x}_{3}+ \\
& 0.03 \mathrm{x}_{2} \mathrm{x}_{4}-0.06 \mathrm{x}_{3} \mathrm{x}_{4}+0.10 \mathrm{x}_{1} \mathrm{x}_{2} \mathrm{x}_{4} \\
& \hat{y}_{5}(\mathbf{x})=5.3+0.51 \mathrm{x}_{1}+0.59 \mathrm{x}_{2}+0.20 \mathrm{x}_{4}-0.3 \mathrm{x}_{1}^{2}+ \\
& 0.08 \mathrm{x}_{1} \mathrm{x}_{2}-0.02 \mathrm{x}_{1} \mathrm{x}_{4}+0.37 \mathrm{x}_{2} \mathrm{x}_{4}-0.32 \mathrm{x}_{1} \mathrm{x}_{2} \mathrm{x}_{4}
\end{aligned}
$$$$
\hat{y}_{6}(\mathbf{x})=153+20 \mathrm{x}_{1}+12 \mathrm{x}_{2}-2 \mathrm{x}_{3}+6 \mathrm{x}_{4}-14 \mathrm{x}_{1}^{2}+12 \mathrm{x}_{4}^{2}+
$$$$
3 \mathrm{x}_{1} \mathrm{x}_{2}-4 \mathrm{x}_{1} \mathrm{x}_{4}+5 \mathrm{x}_{2} \mathrm{x}_{3}+6 \mathrm{x}_{2} \mathrm{x}_{4}-9 \mathrm{x}_{1} \mathrm{x}_{2} \mathrm{x}_{4}
$$

In the present paper, the same data set and conditions were used as in the original work [37]. For the same reason, it was deceded to assign different values to the shape factors $\left(r_{1}^{t}=r_{2}^{t}=r_{3}^{t}=r_{6}^{s}=2.5\right.$; $r_{4}^{S}=r_{5}^{S}=3.5$ ).

After optimization procedure, the optimal solution at the point $\mathbf{X}^{*}=\{12.0,250,5.44,210\}$, with the corresponding estimated response values $\hat{\mathbf{y}}^{*}=\{1.04,0.019$, $75.3,2.96,6.141,184\}$, and the overall desirability $D^{*}=$ 0.75 was found.

All the estimated response values satisfy the limitations given in Table 8 . In this case, the improvement procedure was not necessary.

\subsection{Example 4}

Manohar et al. [38] investigated and optimized the turning of difficult-to-cut annealed superalloy Inconel 718 by using coated carbide tool inserts.

For experimentation, the Taguchi's orthogonal array $\mathrm{L}_{27}\left(3^{13}\right)$ was employed, which is in this case a three-level full factorial design (Table 9).

The design factors (process parameters) of interest as cutting speed $\left(X_{1}\right)$, feed $\left(X_{2}\right)$, and depth of cut $\left(X_{3}\right)$ were taken (Table 10).

The responses as feed ('axial') cutting force $\left(y_{1}\right)$, thrust ('radial') cutting force $\left(y_{2}\right)$, main ('tangential') cutting force $\left(y_{3}\right)$, surface roughness $\left(y_{4}\right)$, and material removal rate $\left(y_{5}\right)$ were selected. These responses were varied in different ranges (Table 11).

Table 9. Design matrix and experimental results

\begin{tabular}{ccccccccc}
\hline & \multicolumn{3}{c}{ Design factors } & \multicolumn{5}{c}{ Responses } \\
\cline { 2 - 9 }$N$ & $X_{1}$ & $X_{2}$ & $X_{3}$ & $y_{I}$ & $y_{2}$ & $y_{3}$ & $y_{4}$ & $y_{5}$ \\
\hline 1 & 40 & 0.20 & 1.0 & 168 & 41 & 66 & 3.12 & 1568 \\
2 & 40 & 0.20 & 1.5 & 178 & 45 & 70 & 3.15 & 2352 \\
3 & 40 & 0.20 & 2.0 & 192 & 52 & 75 & 3.22 & 3136 \\
4 & 40 & 0.25 & 1.0 & 179 & 47 & 69 & 3.24 & 1960 \\
5 & 40 & 0.25 & 1.5 & 190 & 53 & 74 & 3.37 & 2940 \\
6 & 40 & 0.25 & 2.0 & 201 & 58 & 80 & 3.42 & 3920 \\
7 & 40 & 0.30 & 1.0 & 213 & 65 & 85 & 3.60 & 2352 \\
8 & 40 & 0.30 & 1.5 & 222 & 71 & 89 & 3.71 & 3528 \\
9 & 40 & 0.30 & 2.0 & 231 & 78 & 95 & 3.76 & 4704 \\
10 & 50 & 0.20 & 1.0 & 160 & 36 & 59 & 2.98 & 2450 \\
11 & 50 & 0.20 & 1.5 & 171 & 42 & 64 & 3.09 & 3675 \\
12 & 50 & 0.20 & 2.0 & 180 & 48 & 68 & 3.13 & 4900 \\
13 & 50 & 0.25 & 1.0 & 174 & 44 & 62 & 3.20 & 3063 \\
14 & 50 & 0.25 & 1.5 & 182 & 48 & 69 & 3.25 & 4594 \\
15 & 50 & 0.25 & 2.0 & 191 & 54 & 73 & 3.32 & 6125 \\
16 & 50 & 0.30 & 1.0 & 204 & 60 & 79 & 3.56 & 3675 \\
17 & 50 & 0.30 & 1.5 & 211 & 68 & 86 & 3.69 & 5513 \\
18 & 50 & 0.30 & 2.0 & 220 & 75 & 91 & 3.75 & 7350 \\
19 & 60 & 0.20 & 1.0 & 152 & 33 & 55 & 3.08 & 3528 \\
20 & 60 & 0.20 & 1.5 & 160 & 39 & 60 & 3.01 & 5292 \\
21 & 60 & 0.20 & 2.0 & 169 & 46 & 64 & 3.07 & 7056 \\
22 & 60 & 0.25 & 1.0 & 170 & 40 & 58 & 3.15 & 4410 \\
23 & 60 & 0.25 & 1.5 & 177 & 44 & 63 & 3.20 & 6615 \\
24 & 60 & 0.25 & 2.0 & 185 & 49 & 67 & 3.28 & 8820 \\
25 & 60 & 0.30 & 1.0 & 191 & 52 & 65 & 3.49 & 5292 \\
26 & 60 & 0.30 & 1.5 & 199 & 57 & 71 & 3.60 & 7938 \\
27 & 60 & 0.30 & 2.0 & 209 & 63 & 78 & 3.71 & 10584 \\
\hline
\end{tabular}

Table 10. Factors and their levels

\begin{tabular}{cccccc}
\hline \multirow{2}{*}{ Design factors } & \multirow{3}{*}{ Units } & \multicolumn{3}{c}{ Factor levels } \\
& & & $(-1)$ & Midlle & Upper \\
& & $0)$ & $(+1)$ \\
\hline$X_{1}$ & Cutting speed & $\mathrm{m} / \mathrm{min}$ & 40 & 50 & 60 \\
$X_{2}$ & Feed & $\mathrm{mm} / \mathrm{rev}$ & 0.20 & 0.25 & 0.30 \\
$X_{3}$ & Depth of cut & $\mathrm{mm}$ & 1.0 & 1.5 & 2.0 \\
\hline
\end{tabular}

Table 11. Type of response and their specifications

\begin{tabular}{ccccc}
\hline Response & Type & $y_{j}^{\min }$ & $y_{j}^{\max }$ & $r_{j}^{s}$ or $r_{j}^{t}$ \\
\hline$y_{1}$ & STB & 152 & 231 & 1 \\
$y_{2}$ & STB & 33 & 78 & 1 \\
$y_{3}$ & STB & 55 & 95 & 1 \\
$y_{4}$ & STB & 2.98 & 3.88 & 1 \\
$y_{5}$ & LTB & 1.568 & 10.584 & 1 \\
\hline
\end{tabular}

As can be seen from Table 9 and Table 11 the extreme values of the responses within the entire investigated experimental region were considered as the basic constraints for the optimization procedure (see Eqs. (5) and (6)).

The full second-order mathematical model was utilized to find appropriate approximion for the functional relationship between design factors and the response as follows:

$$
\begin{aligned}
& \hat{y}_{1}(\mathbf{x})=235.53-0.13 \mathrm{x}_{1}-927.22 \mathrm{x}_{2}+31.72 \mathrm{x}_{3}-0.0 \mathrm{x}_{1}^{2}+ \\
& 2933.33 \mathrm{x}_{2}^{2}+2.0 \mathrm{x}_{3}^{2}-1.67 \mathrm{x}_{1} \mathrm{x}_{2}-30 \mathrm{x}_{2} \mathrm{x}_{3}-0.23 \mathrm{x}_{1} \mathrm{x}_{3} \\
& \hat{y}_{2}(\mathbf{x})=68.12+1.43 \mathrm{x}_{1}-679.44 \mathrm{x}_{2}+6.17 \mathrm{x}_{3}-0.01 \mathrm{x}_{1}^{2}+ \\
& 2155.56 \mathrm{x}_{2}^{2}+1.56 \mathrm{x}_{3}^{2}-3.67 \mathrm{x}_{1} \mathrm{x}_{2}+10 \mathrm{x}_{2} \mathrm{x}_{3}-0.03 \mathrm{x}_{1} \mathrm{x}_{3}
\end{aligned}
$$


$\hat{y}_{3}(\mathbf{x})=105.44+1.26 \mathrm{x}_{1}-672.78 \mathrm{x}_{2}+4.83 \mathrm{x}_{3}-0.01 \mathrm{x}_{1}^{2}+$

$2000 x_{2}^{2}-0.65 x_{3}^{2}-3.83 x_{1} x_{2}+26.67 x_{2} x_{3}-0.017 x_{1} x_{3}$

$\hat{y} 4(\mathbf{x})=5.24-0.019 \mathrm{x}_{1}-17.24 \mathrm{x}_{2}-0.014 \mathrm{x}_{3}+0.00013 \mathrm{x}_{1}^{2}+$

$41.33 \mathrm{x}_{2}^{2}-0.013 \mathrm{x}_{3}^{2}+0.01 \mathrm{x}_{1} \mathrm{x}_{2}+1.10 \mathrm{x}_{2} \mathrm{x}_{3}-0.0017 \mathrm{x}_{1} \mathrm{x}_{3}$

$\hat{y}_{5}(\mathbf{x})=13654-367.4 x_{1}-36738 x_{2}-6125 x_{3}+1.836 x_{1}^{2}-$

$22.22 x_{2}^{2}-0.22 x_{3}^{2}+735 x_{1} x_{2}+12576.67 x_{2} x_{3}+122.5 x_{1} x_{3}$

In the mentioned work, the individual desirability functions were calculated for the considered responses and subsequently the overall desirability value was obtained. The optimal set of process parameters, under given conditions, corresponding to the maximal value of the overall desirability was identified (run number 20-Table 9).

Numerous investigations have confirmed that responses in machining processes do not deviate much from linear functions $[8,16,22,23,45]$. For instance, in the turning process the material removal rate (MRR) is a linear function of process parameters.

For this reason, by employing the novel desirability function the following shape parameters $r_{1}^{t}=r_{2}^{t}=r_{3}^{t}=$ $=r_{4}^{t}=1.5(\mathrm{LTB})$ and $r_{5}^{s}=0.5(\mathrm{STB})$ were selected.

\subsection{Example 5}

Gunaraj and Murugan [39,40] reported results of an analysis and optimization into the submerged arc welding (SAW), which is one of the major processing technology in metal industry.

The chosen design matrix was a five-level, fourfactor central composite rotatable design, consisting of 31 combinations of design factor levels.

Details of the experimental design, procedures, and design matrix are given in the original paper [39].

The process factor levels with their units and notations are given in Table 12.

Table 12. Factors and their levels

\begin{tabular}{|c|c|c|c|c|c|c|c|}
\hline \multirow{2}{*}{\multicolumn{2}{|c|}{$\begin{array}{l}\text { Design } \\
\text { factors }\end{array}$}} & \multirow{2}{*}{ Unit } & \multicolumn{5}{|c|}{ Factor levels } \\
\hline & & & -2 & -1 & 0 & +1 & +2 \\
\hline$x_{1}$ & $\begin{array}{l}\text { Welding } \\
\text { voltage }\end{array}$ & $\mathrm{V}$ & 24 & 6 & 28 & 30 & 32 \\
\hline$x_{2}$ & $\begin{array}{c}\text { Wire } \\
\text { feed rate }\end{array}$ & $\frac{\mathrm{m}}{\min }$ & 0.7 & 0.93 & 1.16 & 1.39 & 1.62 \\
\hline$x_{3}$ & $\begin{array}{l}\text { Welding } \\
\text { speed }\end{array}$ & $\frac{\mathrm{m}}{\min }$ & 0.43 & 0.51 & 0.59 & 0.67 & 0.75 \\
\hline$x_{4}$ & $\begin{array}{l}\text { Nozzle- } \\
\text { to-plate } \\
\text { distance }\end{array}$ & $\mathrm{mm}$ & 30.0 & 32.5 & 35.0 & 37.5 & 40.0 \\
\hline
\end{tabular}

The responses as penetration $\left(y_{1}\right)$, reinforcement $\left(y_{2}\right)$, width of the bead $\left(y_{3}\right)$, area of penetration $\left(y_{4}\right)$, area of reinforcement $\left(y_{5}\right)$, dilution of the bead $\left(y_{6}\right)$, and total weld bead volume $\left(y_{7}\right)$ were selected.

The responses representing the weld bead quality parameters were expressed in the form of full secondorder polynomial.

The design factors are given in their coded form. The coded design factors for intermediate values were calculated from the following relationship:

$$
x_{i}=2 \frac{2 X_{i}-\left(X_{i}^{\max }+X_{i}^{\min }\right)}{X_{i}^{\max }-X_{i}^{\min }}
$$

where $X_{i}$ is any value of the process factor (natural factor), $X_{i}^{\mathrm{min}}$ is the lower level of the process factor, and $X_{i}^{\max }$ is the upper level of the process factor.

Gunaraj and Murugan [40] employed the quasiNewton method to optimize this multi-response problem (which belongs to one of the most popular methods from a class of nonlinear constrained optimization techniques).

After calculating the unknown coefficients in the mathematical model for predicting the weld bead geometry, the following regression equations were obtained:

$$
\begin{aligned}
& \hat{y}_{1}(\mathbf{x})=3.5714-0.1125 \mathrm{x}_{1}+0.3333 \mathrm{x}_{2}-0.2167 \mathrm{x}_{3}+ \\
& 0.0484 \mathrm{x}_{1}^{2}+0.0959 \mathrm{x}_{2}^{2}+0.0334 \mathrm{x}_{3}^{2}-0.0079 \mathrm{x}_{4}^{2}- \\
& 0.0450 \mathrm{x}_{1} \mathrm{x}_{2}+0.0400 \mathrm{x}_{1} \mathrm{x}_{3}+0.0037 \mathrm{x}_{1} \mathrm{x}_{4}- \\
& 0.0112 \mathrm{x}_{2} \mathrm{x}_{3}-0.0075 \mathrm{x}_{2} \mathrm{x}_{4}+0.0825 \mathrm{x}_{3} \mathrm{x}_{4} \\
& \hat{y}_{2}(\mathbf{x})=1.27-0.0704 \mathrm{x}_{1}+0.1587 \mathrm{x}_{2}-0.1829 \mathrm{x}_{3}- \\
& 0.0338 \mathrm{x}_{4}+0.0715 \mathrm{x}_{1}^{2}+0.0852 \mathrm{x}_{2}^{2}+0.1527 \mathrm{x}_{3}^{2}+ \\
& 0.0127 \mathrm{x}_{4}^{2}+0.0169 \mathrm{x}_{1} \mathrm{x}_{2}+0.0319 \mathrm{x}_{1} \mathrm{x}_{3}-0.0144 \mathrm{x}_{1} \mathrm{x}_{4}- \\
& 0.0031 \mathrm{x}_{2} \mathrm{x}_{3}-0.0194 \mathrm{x}_{2} \mathrm{x}_{4}+0.0256 \mathrm{x}_{3} \mathrm{x}_{4} \\
& \hat{y}_{3}(\mathbf{x})=10.7543+1.1883 \mathrm{x}_{1}+0.4533 \mathrm{x}_{2}-1.9042 \mathrm{x}_{3}+ \\
& 0.2333 \mathrm{x}_{4}+0.4110 \mathrm{x}_{1}^{2}-0.1727 \mathrm{x}_{2}^{2}+0.2898 \mathrm{x}_{3}^{2}+ \\
& 0.1160 \mathrm{x}_{4}^{2}-0.0463 \mathrm{x}_{1} \mathrm{x}_{2}-0.6425 \mathrm{x}_{1} \mathrm{x}_{3}-0.1500 \mathrm{x}_{1} \mathrm{x}_{4}- \\
& 0.3462 \mathrm{x}_{2} \mathrm{x}_{3}+0.0913 \mathrm{x}_{2} \mathrm{x}_{4}-0.2900 \mathrm{x}_{3} \mathrm{x}_{4} \\
& \hat{y}_{4}(\mathbf{x})=21.5571+1.0458 \mathrm{x}_{1}+1.8542 \mathrm{x}_{2}-1.6042 \mathrm{x}_{3}- \\
& 0.2125 \mathrm{x}_{4}+0.0409 \mathrm{x}_{1}^{2}+0.2909 \mathrm{x}_{2}^{2}-0.0966 \mathrm{x}_{3}^{2}+ \\
& 0.1534 \mathrm{x}_{4}^{2}+0.1437 \mathrm{x}_{1} \mathrm{x}_{2}-0.2063 \mathrm{x}_{1} \mathrm{x}_{3}+0.0562 \mathrm{x}_{1} \mathrm{x}_{4}- \\
& 0.2437 \mathrm{x}_{2} \mathrm{x}_{3}-0.1562 \mathrm{x}_{2} \mathrm{x}_{4}-0.1562 \mathrm{x}_{3} \mathrm{x}_{4} \\
& \hat{y}_{5}(\mathbf{x})=21.4429+0.4429 \mathrm{x}_{1}+0.1871 \mathrm{x}_{2}-1.7559 \mathrm{x}_{3}+ \\
& 2.1079 \mathrm{x}_{4}+1.3886 \mathrm{x}_{1}^{2}-0.3889 \mathrm{x}_{2}^{2}+1.2236 \mathrm{x}_{3}^{2}+ \\
& 0.6148 \mathrm{x}_{4}^{2}+0.4056 \mathrm{x}_{1} \mathrm{x}_{2}-0.0469 \mathrm{x}_{1} \mathrm{x}_{3}+0.1406 \mathrm{x}_{1} \mathrm{x}_{4}- \\
& 0.9431 \mathrm{x}_{2} \mathrm{x}_{3}+0.7694 \mathrm{x}_{2} \mathrm{x}_{4}-0.3256 \mathrm{x}_{3} \mathrm{x}_{4} \\
& \hat{y}_{6}(\mathbf{x})=47.2857+0.7375 \mathrm{x}_{1}+2.5042 \mathrm{x}_{2}-0.2542 \mathrm{x}_{3}- \\
& 2.2542 \mathrm{x}_{4}-1.3516 \mathrm{x}_{1}^{2}-0.7141 \mathrm{x}_{2}^{2}-1.3141 \mathrm{x}_{3}^{2}- \\
& 0.4516 \mathrm{x}_{4}^{2}-0.0937 \mathrm{x}_{1} \mathrm{x}_{2}-0.2562 \mathrm{x}_{1} \mathrm{x}_{3}-0.3187 \mathrm{x}_{1} \mathrm{x}_{4}+ \\
& 0.4313 \mathrm{x}_{2} \mathrm{x}_{3}-0.9062 \mathrm{x}_{2} \mathrm{x}_{4}+0.1563 \mathrm{x}_{3} \mathrm{x}_{4} \\
& \hat{y}_{7}(\mathbf{x})=45.8857+1.5792 \mathrm{x}_{1}+2.2042 \mathrm{x}_{2}-3.5042 \mathrm{x}_{3}+ \\
& 2.0208 \mathrm{x}_{4}+1.66922_{1}^{2}+0.1692 \mathrm{x}_{2}^{2}+1.3692 \mathrm{x}_{3}^{2}+ \\
& 0.9692 \mathrm{x}_{4}^{2}+0.2813 \mathrm{x}_{1} \mathrm{x}_{2}-0.2062 \mathrm{x}_{1} \mathrm{x}_{3}+0.4813 \mathrm{x}_{1} \mathrm{x}_{4}- \\
& 0.8687 \mathrm{x}_{2} \mathrm{x}_{3}+0.6438 \mathrm{x}_{2} \mathrm{x}_{4}-0.7687 \mathrm{x}_{3} \mathrm{x}_{4}
\end{aligned}
$$

The total weld bead volume was adopted as the primary response, while the remaining weld bead quality parameters were treated as constraint functions (priority-based optimization approach) [40]. 
Datta et al. [41] used the same experimental data and regression equations from previous researches [39], [40], with the aim of presenting the features of a desirability function approach, coupled with RSM, to solve multi-response optimization problems in SAW.

Table 13 depicts the response types as well as bound values for all the responses. In this example, all the observed responses are of one-sided type and, consequently, one of the given bounds merely serves to determine the corresponding individual desirability function.

The individual desirability functions, for each of the responses, have been selected in such a way that their target values are the same as those obtained after optimization done by Gunaraj and Murugan [40].

In this paper, in order to compare the results of previous researches [39], [40], [41], and those obtained by using the novel desirability method [29], the original experiment and all the same conditions were utilized.

For the same reason, optimal response values (for each of the optimal design factor settings) were calculated by the same equations.

Table 13. Type of response and their specifications

\begin{tabular}{ccccc}
\hline Response & Type & $y_{j}^{\min }$ & $y_{j}^{\max }$ & $r_{j}^{s}=r_{j}^{t}$ \\
\hline$y_{1}$ & LTB & 3.00 & 3.07 & 1 \\
$y_{2}$ & STB & 1.28 & 1.80 & 1 \\
$y_{3}$ & STB & 8.33 & 15.00 & 1 \\
$y_{4}$ & STB & 18.30 & 20.00 & 1 \\
$y_{5}$ & STB & 20.21 & 22.00 & 1 \\
$y_{6}$ & STB & 38.00 & 50.00 & 1 \\
$y_{7}$ & STB & 41.33 & 15.00 & 1 \\
\hline
\end{tabular}

In this example, the "default" shape parameters were selected for each of the individual desirability functions $r_{j}^{s}=r_{j}^{t}=2.5$.

The initial solution at the optimal point $\mathbf{x}^{*}=\{-0.257,-2.000,0.604,-0.075\}$, with the corresponding estimated response values $\hat{\mathbf{y}}^{*}=\{3.182,1.267,8.334,18.144,20.210,37.997,41.462\}$ and the overall desirability $D^{*}=0.999$ was found.

\subsection{Example 6}

Aggarwal et al. [42] studied the CNC turning of AISI P 20 tool steel by using the TiN coated tungsten carbide cutting inserts and liquid nitrogen as a coolant.

Table 14 shows the levels for each chosen input parameter, including cutting speed $\left(X_{1}\right)$, feed $\left(X_{2}\right)$, depth of cut $\left(X_{3}\right)$, and nose radius $\left(X_{4}\right)$.

Table 14. Factors and their levels

\begin{tabular}{cccccc}
\hline & & & \multicolumn{3}{c}{ Factor levels } \\
Design factors & Unit & $\begin{array}{c}\text { Lower } \\
(-1)\end{array}$ & $\begin{array}{c}\text { Middle } \\
(0)\end{array}$ & $\begin{array}{c}\text { Upper } \\
(+1)\end{array}$ \\
\hline$X_{1}$ & Cutting speed & $\mathrm{m} / \mathrm{min}$ & 120 & 160 & 200 \\
$X_{2}$ & Feed & $\mathrm{mm} / \mathrm{rev}$ & 0.10 & 0.12 & 0.14 \\
$X_{3}$ & Depth of cut & $\mathrm{mm}$ & 0.20 & 0.35 & 0.50 \\
$X_{4}$ & Nose radius & $\mathrm{mm}$ & 0.40 & 0.80 & 1.20 \\
\hline
\end{tabular}

As responses surface roughness $\left(y_{1}\right)$, tool life $\left(y_{2}\right)$, cutting force $\left(y_{3}\right)$, and power consuption $\left(y_{4}\right)$ were chosen. All the observed responses were varied in different ranges (Table 15).

Table 15. Type of response and their specifications

\begin{tabular}{ccccc}
\hline \multirow{2}{*}{ Response } & Type & $y_{j}^{\min }$ & $y_{j}^{\max }$ & $r_{j}^{s}$ or $r_{j}^{t}$ \\
\hline$y_{1}$ & STB & 0.17 & 0.99 & 1 \\
$y_{2}$ & LTB & 34.00 & 55.50 & 1 \\
$y_{3}$ & STB & 92.15 & 249.94 & 1 \\
$y_{4}$ & STB & 660 & 1780 & 1 \\
\hline
\end{tabular}

The turning process was studied according to threelevel full factorial CCD design. Thirty independent trials were performed under the previously described cutting conditions. Each trial was repeated twice.

For more details, readers are referring to the original paper [42].

For each response the entire experimental region was employed to fit the second-order regression model as follows:

$$
\begin{aligned}
& \hat{y}_{1}(\mathbf{x})=6.975-0.0044 \mathrm{x}_{1}-101.621 \mathrm{x}_{2}-1.087 \mathrm{x}_{3}- \\
& 0.211 \mathrm{x}_{4}+0.00729 \mathrm{x}_{1} x_{3}+4.583 x_{2} x_{3}-2.031 x_{2} x_{4} \\
& +446.774 x_{2}^{2}+0.054 x_{4}^{2} \\
& \hat{y}_{2}(\mathbf{x})=82.205-0.198 \mathrm{x}_{1}+72.021 \mathrm{x}_{2}-13.886 \mathrm{x}_{3}+ \\
& 1.163 \mathrm{x}_{4}+0.078 \mathrm{x}_{1} x_{2}+0.002 x_{1} x_{4}-3.906 x_{2} x_{4}- \\
& 0.521 x_{3} x_{4}-926.535 x_{2}^{2}+16.862 x_{3}^{2}-0.754 x_{4}^{2} \\
& \hat{y}_{3}(\mathbf{x})=-223.496-5.186 \mathrm{x}_{1}+9559.856 \mathrm{x}_{2}+ \\
& 468.183 \mathrm{x}_{3}-19.802 \mathrm{x}_{4}+4.411 \mathrm{x}_{1} x_{2}+0.507 x_{1} x_{3}+ \\
& 0.020 x_{1} x_{4}-1483.542 x_{2} x_{3}-64.922 x_{2} x_{4}+3.427 x_{3} x_{4}+ \\
& 0.015 x_{1}^{2}-34885.526 x_{2}^{2}-172.632 x_{3}^{2}+17.349 x_{4}^{2} \\
& \hat{y}_{4}(\mathbf{x})=261.784+3.559 \mathrm{x}_{1}-6127.924 \mathrm{x}_{2}- \\
& 408.382 \mathrm{x}_{3}+153.655 \mathrm{x}_{4}-6.250 \mathrm{x}_{1} x_{2}+8.333 x_{1} x_{3}+ \\
& 0.156 x_{1} x_{4}+833.333 x_{2} x_{3}-0.00110 x_{1}^{2}+45614.035 x_{2}^{2}+ \\
& 366.472 x_{3}^{2}-0.965 x_{4}^{2}
\end{aligned}
$$

Very high values of coefficients of determination ( $R_{1}^{2}=0.983, R_{2}^{2}=R_{3}^{2}=R_{4}^{2}=0.999$ ) indicate that the presented regression equations quite adequately explained the variability in the turning process.

In such circumstances, it has been shown that the desirability functions may be less convex i.e. more concave. Generally, an estimated response with poorer prediction should have less impact on optimization [6]. Therefore, for the first (initial) solution by employing the novel desirability function the shape parameters $r_{2}^{s}=r_{3}^{t}=r_{4}^{t}=2.0$ and $r_{1}^{t}=0.20$ were chosen.

After optimization procedure, the initial optimal solution at the point $\mathbf{X}^{*}=\{120,0.10,0.20,0.95\}$, with the corresponding estimated response values $\hat{\mathbf{y}}^{*}=\{0.46,55.40,93.08,753.90\}$, and the overall desirability $D^{*}=0.990$ was found.

In this case, the improvement procedure was not necessary. 


\section{DISCUSSION}

Looking at all examples, it is observed that there is no run in experimental matrices that provides the optimal factor levels combination for simultaneous optimization of all considered responses.

Tables 16-21 compare the results obtained for all considered experiments by the proposed method with the results reported by other researchers.

As Table 16 shows, the initial solution of Jeong and Kim [26] is not satisfactory. After the third iteration (using shape and bound mode) these authors obtained a quite satisfactory solution with an optimal point $\mathbf{x}^{*}=\{-0.157,1.219,-0.604\}$ and the corresponding responses $\hat{\mathbf{y}}^{*}=\{139.82,1239.1,446.51,73.93\}$, as well as overall desirability $D^{*}=0.626$.

However, once again, this solution is no better than the improved solution obtained by the method proposed in this paper (see Section 4.1.).

In this paper, in Example 5, the focus was on an alternative method. Namely, the results of the method proposed are summarized and compared with those of Gunaraj and Murugan [40] who applied the classical nonlinear constrained method. At the same time, it is worth noting that the approaches by Gunaraj and Murugan [40] and Datta et al. [41] produce almost identical results.

Table 16. Comparison of results for example 1: Methods from literature and approach proposed

\begin{tabular}{cccccc}
\hline $\begin{array}{c}\text { Metho } \\
\mathrm{d}\end{array}$ & $\begin{array}{c}\text { Deringer } \\
\text {-Suich }\end{array}$ & $\begin{array}{c}\text { Park S. } \\
\text {-Park J. }\end{array}$ & $\begin{array}{c}\text { Jeong } \\
\text {-Kim }\end{array}$ & $\begin{array}{c}\text { Lee } \\
\text { et al. }\end{array}$ & $\begin{array}{c}\text { Proposed } \\
\text { method }\end{array}$ \\
\hline$x_{1}$ & -0.050 & -0.158 & -0.499 & 0.18 & 0.126 \\
$x_{2}$ & 0.145 & 0.437 & 1.029 & 0.51 & 0.406 \\
$x_{3}$ & -0.868 & -0.879 & 1.156 & -1.06 & -1.241 \\
\hline$y_{1}$ & 129.5 & 130.38 & 157.79 & $\mathbf{1 3 1 . 6 2}$ & 127.1 \\
$y_{2}$ & 1300.0 & 1300.02 & 1689.5 & 1408.1 & $\mathbf{1 4 4 3 . 0}$ \\
$y_{3}$ & 465.7 & $\mathbf{4 7 1 . 0}$ & $346.6^{*}$ & 449.42 & 469.3 \\
$y_{4}$ & $\mathbf{6 8 . 0}$ & 69.62 & $76.43^{*}$ & 68.8 & $\mathbf{6 8 . 0}$ \\
\hline$D$ & 0.583 & - & - & 0.481 & $\mathbf{0 . 7 0 2}$ \\
\hline \multicolumn{6}{c}{ The values in bold indicate the best solution } \\
* Response outside of acceptable values
\end{tabular}

Table 17. Comparison of results for example 2: Methods from literature and approach proposed

\begin{tabular}{ccccc}
\hline Method & $\begin{array}{c}\text { Del Castillo } \\
\text { et al. }\end{array}$ & $\begin{array}{c}\text { Ortiz } \\
\text { et al. }\end{array}$ & $\begin{array}{c}\text { Ch ng } \\
\text { et al. }\end{array}$ & $\begin{array}{c}\text { Proposed } \\
\text { method }\end{array}$ \\
\hline$X_{1}$ & 84.16 & 74.55 & 78.26 & 103.64 \\
$X_{2}$ & 450.00 & 472.90 & 450.00 & 424.30 \\
$X_{3}$ & 329.87 & 332.75 & 336.54 & 350.00 \\
\hline$y_{1}$ & 186.0 & 187.0 & 185.0 & $\mathbf{1 9 0 . 1}$ \\
$y_{2}$ & 174.5 & 176.7 & 174.6 & $\mathbf{1 7 8 . 4}$ \\
$y_{3}$ & 172.1 & 173.8 & 172.3 & $\mathbf{1 8 0 . 7}$ \\
$y_{4}$ & 192.6 & 192.9 & $\mathbf{1 9 0 . 0}$ & 191.5 \\
$y_{5}$ & 173.1 & 174.2 & 172.5 & $\mathbf{1 7 4 . 7}$ \\
$y_{6}$ & $\mathbf{1 8 5 . 0}$ & 186.2 & 185.4 & 189.6 \\
\hline$D$ & 0.306 & 0.408 & 0.108 & $\mathbf{0 . 5 8 9}$ \\
\hline \multicolumn{5}{c}{ The values in bold indicate the best solution } \\
\hline
\end{tabular}

Example 6 was also discussed by Noorossana et al. [43]. In their work, an ANN approach is presented which utilizes a process capability index (PCI) to combine multiple responses into a single function. In
Table 21, their optimal (iterative) solutions are compared to those obtained from dissimilar approaches.

As already established, the first (initial) solutions obtained by the proposed method simultaneously satisfy all specific requirements and gives good balance between the responses.

Obviously, a better and more reliable solution can be achieved using the improvement procedure described above, based on the optimal setting of shape parameters.

This approach can also be used to generate an initial solution. However, because it is a tedious and timeconsuming work, choosing the 'default' shape para-meters for individual desirability functions remains the first option.

Generally speaking, the pair-wise comparisons clearly show that different approaches give similar or comparable results. However, looking at all the results concurrently, it is evident that the proposed method outperforms the others to some extent. Similar observations were made in the paper [29].

The performance supremacy of the proposed method over some known approaches should be verified by testing the larger number of complex optimization problems. The truth is, even in such a case where above qualitative description is acceptable, it does not mean that the proposed method is the best. Namely, according to the no free lunch (NFL) theorem [46], no such method exists. In other words, none of the optimization methods can be claimed to be superior to others for each specific optimization problem.

Table 18. Comparison of results for example 3: Methods from literature and approach proposed

\begin{tabular}{cccc}
\hline Method & $\begin{array}{c}\text { Derringer- } \\
\text { Suich } \\
\text { approach }^{\mathrm{a}}\end{array}$ & $\begin{array}{c}\text { Kim-Lin } \\
\text { approach }^{\mathrm{a}}\end{array}$ & $\begin{array}{c}\text { Proposed } \\
\text { method }\end{array}$ \\
\hline$X_{1}$ & 7.20 & 5.00 & 12.00 \\
$X_{2}$ & 250 & 250 & 250 \\
$X_{3}$ & 5.50 & 5.60 & 5.44 \\
$X_{4}$ & 210 & 202 & 210 \\
\hline$y_{1}$ & 1.22 & 2.16 & $\mathbf{1 . 0 4}$ \\
$y_{2}$ & 0.023 & 0.027 & $\mathbf{0 . 0 1 9}$ \\
$y_{3}$ & 77.4 & 80.2 & $\mathbf{7 5 . 3}$ \\
$y_{4}$ & 3.03 & $\mathbf{3 . 2 7}$ & 2.96 \\
$y_{5}$ & 6.39 & 5.87 & $\mathbf{6 . 4 1}$ \\
$y_{6}$ & 183 & 155 & $\mathbf{1 8 4}$ \\
\hline$D$ & 0.71 & 0.48 & $\mathbf{0 . 7 5}$ \\
\hline \multicolumn{4}{c}{ The values in bold indicate the best solution } \\
\hline \multicolumn{4}{c}{ Calculated by Mangili et al. [37] }
\end{tabular}

Table 19. Comparison of results for example 4: Methods from literature and approach proposed

\begin{tabular}{ccc}
\hline Method & Manohar et al. & Proposed method \\
\hline$X_{1}$ & 60 & 60 \\
$X_{2}$ & 0.2 & 0.215 \\
$X_{3}$ & 1.5 & 1.970 \\
$y_{1}$ & $\mathbf{1 6 0}$ & 165.91 \\
$y_{2}$ & 39 & $\mathbf{3 8 . 8 7}$ \\
$y_{3}$ & 60 & $\mathbf{5 7 . 3 6}$ \\
$y_{4}$ & $\mathbf{3 . 0 1}$ & 3.05 \\
$y_{5}$ & 5292 & $\mathbf{6 1 2 9}$ \\
$D$ & 0.771 & $\mathbf{0 . 9 5 5}$ \\
\hline
\end{tabular}

The values in bold indicate the best solution 
Table 20. Comparison of results for example 5: Methods from literature and approach proposed

\begin{tabular}{cccc}
\hline Method & $\begin{array}{c}\text { Gunaraj } \\
\text {-Murugan }\end{array}$ & $\begin{array}{c}\text { Datta } \\
\text { et al. }\end{array}$ & $\begin{array}{c}\text { Proposed } \\
\text { method }\end{array}$ \\
\hline$x_{1}$ & 0 & 0 & -0.257 \\
$x_{2}$ & -2.000 & -2.000 & -2.000 \\
$x_{3}$ & 0.625 & 1.325 & 0.604 \\
$x_{4}$ & -0.160 & 0 & -0.075 \\
$y_{1}$ & 3.169 & 3.090 & $\mathbf{3 . 1 8 2}$ \\
$y_{2}$ & $\mathbf{1 . 2 4 0}$ & 1.243 & 1.267 \\
$y_{3}$ & 8.537 & 8.513 & $\mathbf{8 . 3 3 4}$ \\
$y_{4}$ & 18.280 & 18.277 & $\mathbf{1 8 . 1 4 4}$ \\
$y_{5}$ & $\mathbf{2 0 . 0 3 0}$ & 20.073 & 20.210 \\
$y_{6}$ & 38.253 & 38.210 & $\mathbf{3 7 . 9 9 7}$ \\
$y_{7}$ & 41.569 & 41.585 & $\mathbf{4 1 . 4 6 2}$ \\
$D$ & - & 0.972 & $\mathbf{0 . 9 9 9}$ \\
\hline
\end{tabular}

The values in bold indicate the best solution

${ }^{a}$ Nonlinear constrained optimization method

b Standard Derringer's desirability optimization method

Table 21. Comparison of results for example 6: Methods from literature and approach proposed

\begin{tabular}{|c|c|c|c|c|}
\hline \multirow[b]{2}{*}{ Method } & \multicolumn{2}{|c|}{ Noorossana et al. ${ }^{\mathrm{a}}$} & \multirow[b]{2}{*}{$\begin{array}{l}\text { Aggarwal } \\
\text { et al. }\end{array}$} & \multirow[b]{2}{*}{$\begin{array}{c}\text { Proposed } \\
\text { method }\end{array}$} \\
\hline & $\begin{array}{l}\text { 1st } \\
\text { iteration }\end{array}$ & $\begin{array}{l}\text { 2nd } \\
\text { iteration }\end{array}$ & & \\
\hline$X_{1}$ & - & - & 120 & 120 \\
\hline$X_{2}$ & - & - & 0.10 & 0.10 \\
\hline$X_{3}$ & - & - & 0.20 & 0.20 \\
\hline$X_{4}$ & - & - & 1.20 & 0.95 \\
\hline$y_{1}$ & 0.31 & 0.17 & 0.38 & 0.46 \\
\hline$y_{2}$ & 50.64 & 40.50 & 55.23 & 55.40 \\
\hline$y_{3}$ & 156.12 & 134.34 & 95.80 & 93.08 \\
\hline$y_{4}$ & 1012.9 & 871.15 & 781.66 & 753.90 \\
\hline$D$ & $\begin{array}{l}\cdots \\
-\end{array}$ & - & 0.890 & 0.990 \\
\hline
\end{tabular}

The values in bold indicate the best solution

${ }^{\text {a }}$ ANN-based PCI optimization approach

\section{CONCLUSION}

During the last two decades, the desirability function has attracted worldwide attention and has been recognized as a useful and powerful tool in multiresponse optimization methodologies due to its novelty and remarkable performance.

This paper deals with the application of a newly recommended desirability function in multi-response optimization of higher-dimensional problems (in terms of the number of design factors and the number of observed responses).

The efficiency and accuracy of the proposed method has been successfully tested by using six practical examples with specific characteristics taken from previously published articles.

The optimal solutions obtained in all examples by applying the novel desirability function contain the highest overall desirability in comparison with the existing desirability functions, implying the best balance between the considered quantitatiive responses.

In general, the presented results suggest the superiority of the proposed method over the other approaches known in the literature. Therefore, it is concluded that this method represents an excellent approach at solving a wide area of multi-response optimization problems.

In addition, an exact method was suggested (developed under the RSM framework) for determining the favorable shape parameters in desirability functions. Consequently, due to the proposed procedure, it does not require any (arbitrarily) specification of the shape parameters before the optimization procedure. This method was successfully applied in the first example.

Finally, like many other desirability function approaches, the method proposed can be easily understood and implemented by researchers and practitioners with little mathematical or statistical knowledge.

\section{APPENDIX}

The table below lists some of the factorial design (saturated or near-saturated), with three or more factor levels, which are suitable for the analysis shown in this paper. The recommended designs (denoted by asterisk) were selected according to the number of runs and their performances. It is known that using a proper transformation one can get some of the hybrid ("parsimonious") designs. Among these designs, some of them with many factors have good space-filling properties, but this can be a limiting feature in their application. It is natural to be expected that designs with equal sample sizes have different performance. Also, it should be expected that larger designs have better performance than smaller designs, but it is not always the case. The formulation "incomplete mathematical model" means that the given model takes into account only the main effects (without interactions).

Today, computers can help researchers in building a (approximately) optimal experimental design ("best" with respect to some optimality criterion). Computergenerated design can be an alternatively option, but the researcher in the RSM frame should primarily find out an appropriate standard design from the available collection.

\begin{tabular}{|c|c|c|c|c|}
\hline Design factors $(\mathrm{k})$ & Alternative designs & $\begin{array}{c}\text { Factor levels } \\
\text { (n) }\end{array}$ & $\begin{array}{l}\text { Runs } \\
(\mathrm{N})\end{array}$ & $\begin{array}{l}\text { Model parameters } \\
\text { (p) }\end{array}$ \\
\hline \multirow{8}{*}{2} & Box-Draper design (BDD) $^{*}$ & 3 & 6 & \multirow{6}{*}{6} \\
\hline & Rehtschaffner design ${ }^{*}$ & 3 & 6 & \\
\hline & Doehlert design ${ }^{*}$ & 7 & 7 & \\
\hline & Hartley design $^{*}$ & 3 & 7 & \\
\hline & Taguchi design $\left(\mathrm{L}_{9}\right)$ & 3 & 9 & \\
\hline & Central composite design (CCD) & 3 & 10 & \\
\hline & Taguchi design $\left(\mathrm{L}_{9}\right)^{*}$ & 3 & 9 & \\
\hline & Box-Draper design (BDD) ${ }^{*}$ & 4 & 10 & \\
\hline
\end{tabular}




\begin{tabular}{|c|c|c|c|c|}
\hline \multirow{10}{*}{3} & Rehtschaffner design $^{*}$ & 3 & 10 & \multirow{10}{*}{10} \\
\hline & Hoke design $\left(\mathrm{D}_{2}\right)^{*}$ & 3 & 10 & \\
\hline & Koshal design ${ }^{*}$ & 3 & 10 & \\
\hline & Notz design ${ }^{*}$ & 3 & 10 & \\
\hline & Draper-Lin design (DLD) ${ }^{*}$ & 3 & 10 & \\
\hline & Roquemore hybrid design $\left(\mathrm{D}_{311 \mathrm{~B}}\right)^{*}$ & 9 & 11 & \\
\hline & Hartley design ${ }^{*}$ & 3 & 11 & \\
\hline & Small composite design (SCD) & 5 & 11 & \\
\hline & Pesocinsky design & 3 & 13 & \\
\hline & Doehlert design & 13 & 13 & \\
\hline \multirow{10}{*}{4} & Taguchi design $\left(\mathrm{L}_{9}\right)^{*}$ & 3 & 9 & \multirow{10}{*}{15} \\
\hline & Jones-Nachtsheim design ${ }^{*}$ & 3 & 9 & \\
\hline & Box-Draper design (BDD) ${ }^{*}$ & 4 & 15 & \\
\hline & Rehtschaffner design ${ }^{*}$ & 3 & 15 & \\
\hline & Notz design ${ }^{*}$ & 3 & 15 & \\
\hline & Hoke design $\left(\mathrm{D}_{2}\right)^{*}$ & 3 & 15 & \\
\hline & Roquemore hybrid design $\left(\mathrm{D}_{416 \mathrm{C}}\right)^{*}$ & 8 & 16 & \\
\hline & Taguchi design $\left(\mathrm{L}_{16}{ }{ }^{*}\right.$ & 4 & 16 & \\
\hline & Draper-Lin design (DLD) ${ }^{*}$ & 3 & 16 & \\
\hline & Hartley design & 3 & 17 & \\
\hline \multirow{6}{*}{5} & Jones-Nachtsheim design* & 3 & 11 & \multirow{6}{*}{21} \\
\hline & Taguchi design $\left(\mathrm{L}^{\prime}{ }_{16}\right)^{*}$ & 4 & 16 & \\
\hline & Draper-Lin design (DLD) ${ }^{*}$ & 3 & 21 & \\
\hline & Box-Draper design (BDD) ${ }^{*}$ & 4 & 21 & \\
\hline & Rehtschaffner design ${ }^{*}$ & 3 & 21 & \\
\hline & Taguchi design $\left(\mathrm{L}_{25}\right)$ & 5 & 25 & \\
\hline \multirow{6}{*}{6} & Jones-Nachtsheim design & 3 & 13 & \multirow{6}{*}{28} \\
\hline & Taguchi design $\left(\mathrm{L}_{25}\right)^{*}$ & 5 & 25 & \\
\hline & Taguchi design $\left(\mathrm{L}_{27}\right)^{*}$ & 3 & 27 & \\
\hline & Box-Draper design (BDD) ${ }^{*}$ & 4 & 28 & \\
\hline & Rehtschaffner design $^{*}$ & 3 & 28 & \\
\hline & Draper-Lin design (DLD) ${ }^{*}$ & 3 & 28 & \\
\hline
\end{tabular}

\section{REFERENCES}

[1] Griva, I., Nash, S.G. and Sofer, A.: Linear and nonlinear optimization. Philadelphia: Society for Industrial and Applied Mathematics, 2009.

[2] Ehrgott, M.: Multicriteria optimization, 2nd ed., Berlin/ Heidelberg: Springer, 2005.

[3] Rao, S.S.: Engineering Optimization: Theory and Practice, New York: John Wiley \& Sons, 2020.

[4] Murphy T.E., Tsui, K.L. and Allen, J.K.: A review of robust design methods for multiple responses. Res. Eng. Des. Vol. 16, No 3, pp. 118-132, 2005.

[5] Costa, N.R., Lourenco, J.: Multiresponse problems: desirability and other optimization approaches. J. Chemom. Vol. 30, pp. 702-714, 2016.

[6] Kim, K.J., Lin, D.K.: Simultaneous optimization of mechanical properties of steel by maximizing exponential desirability function. J. R. Stat. Soc. CAppl. Vol. 49, No 3, pp. 311-325, 2000.

[7] Bikbulatov, E.S. et al: Harrington's desirability function for natural ater quality assessment. Russ. J. Gen. Chem. Vol. 81, No 13, pp. 2694-2704, 2011.

[8] Baraskar, S.S., Banwait, S.S. and Laroiya, S.C.: Multi-objective optimisation of electrical discharge machining process using Derringer's desirability function approach. Int. J. Mater. Eng. Innov. Vol. 2, No 3/4, pp. 203-221, 2011.

[9] Kolda, T.G., Lewis, R.M. and Torczon, V.: Optimization by direct search: New perspectives on some classical and modern methods. SIAM Rev. Vol. 45, No 3, pp. 385-482, 2003.

[10] Ortiz, M.C. et al.: Vectorial optimization as a methodical alternative to desirability function. Chemometr. Intell. Lab. Vol. 83, pp. 157-168, 2006.

[11]Ilgin, M.A., Gupta, M.: Physical programming: A review of the state of the art. Stud. Inform. Control. Vol. 21, No 4, pp. 349-366, 2012.

[12] Šibalija, T.V., Majstorović, V.D.: Novel Approach to Multi-Response Optimisation for Correlated Responses. FME Transactions. Vol. 38, No 1, pp. 39-48, 2010.

[13] Gautam G.D., Mishra D.R.: Multiple Kerf Quality Optimization in Laser Cutting of BFRP Composite using Grey Relational based Genetic Algorithm. FME Transactions, Vol. 48, pp. 636-650, 2020.

[14]Huang, F., Wang, H., Gu, J. and Sun, Q.: Ant colony optimization approach based on precedence 
constraint matrix for flexible process planning. Journal of Engg. Research, Vol. 8, No 1, pp. 272293, 2020.

[15] Roy, R., Hinduja, S. and Teti, R.: Recent advances in engineering design optimization: Challenges and future trends. CIRP Ann-Manuf. Techn. Vol. 57, pp. 697-715, 2008.

[16] Satishkumar, S., Asokan, P.: Selection of optimal conditions for CNC multitool drilling system using non-traditional techniques. Int. J. Mater. Mech. Manuf. Vol. 3, No 1-2, pp. 190-207, 2008.

[17] Mirjalili, S., Mirjalili, S.M. and Lewis A.: Grey wolf optimizer. Adv. Eng. Softw. Vol. 69, pp. 4661, 2014.

[18] Patnaik, S., Yang, X-S., Nakamatsu, K. (Editors): Nature-Inspired Computing and Optimization: Theory and Applications. Cham, Springer International Publishing AG, 2017.

[19]Rao, R.V., Savsani, V.J. and Vakharia, D.P.: Teaching-learning-based optimization: A novel method for constrained mechanical design optimization problems. Comput. Aided. Des. Vol. 43, No 3, pp. 303-315, 2011.

[20] Atashpaz-Gargari, E., Lucas, C.: Imperialist competitive algorithm: An algorithm for optimization inspired by imperialistic competition, In: IEEE Congress on Evolutionary Computation, Singapore, pp. 4661-4667, 2007.

[21] Nguyena, A.T., Reitera, S. and Rigo, P.: A review on simulation-based optimization methods applied to building performance analysis. Appl. Energy. Vol. 113,pp. 1043-1058, 2014.

[22] Mukherjee, I., Ray, P.K.: A review of optimization techniques in metal cutting processes. Comput. Ind. Eng. Vol. 50, pp. 15-34, 2006.

[23]Rao, R.V., Kalyankar, V.D.: Optimization of modern machining processes using advanced optimization techniques: a review. Int. J. Adv. Manuf. Tech. Vol. 73, pp. 1159-1188, 2014.

[24]Hadjmohammadi, M., Salary, M.: Application of sigmoidal transformation functions in optimization of micellar liquid chromatographic separation of six quinolone antibiotics. J. Chromatogr. Sci. Vol. 54, No 3, pp. 429-435, 2016.

[25]Costa, N.R., Lourenço, J. and Pereira, Z.L.: Desirability function approach: A review and performance evaluation in adverse conditions. Chemometr. Intell. Lab. Vol. 107, No 2, pp. 234244, 2011.

[26]Jeong, I., Kim, K.: An interactive desirability function method to multiresponse optimization. Eur. J. Oper. Res. Vol. 195, pp. 412-426, 2009.

[27] Harrington, E.C.: The desirability function. Ind. Qual. Control. Vol. 21, pp. 494-498, 1965.

[28] Derringer, G., Suich, R.: Simultaneous optimization of several response variables. J. Qual. Technol. Vol. 12, No 4, pp. 214-219, 1980.

[29] Marinković, V.: A novel desirability function for multi-response optimization and its application in chemical engineering. Chem. Ind. Chem. Eng. Q. Vol. 26, No 3, pp. 309-319, 2020.

[30] Jeong, I., Kim, K.: Interactive desirability function approach to multi-response surface optimization. Int. J. Reliab. Qual. Saf. Eng. Vol. 10, No 2, pp. 205-217, 2003.

[31] Quirante, T., Sebastian, P. and Ledoux, Y.: A tradeoff function to tackle robust design problems in engineering. J. Eng. Design. Vol. 24, No 1, pp. 6481, 2013.

[32] Castillo, E.D., Montgomery, D.C. and Mc Carville, D.R.: Modified desirability functions for multiple response optimization. J. Qual. Technol. Vol. 28, No 3, pp. 337-345, 1996.

[33]Ch'ng, C.K., Quah, S.H. and Low, H.C.: A new approach for multiple-response optimization. Qual. Eng. Vol. 17, pp. 621-626, 2005.

[34] Park, S.H., Park, J.O.: Simultaneous optimization of multiple response using weighted desirability function. J. Korean Soc. Qual. Manag. Vol. 25, pp. 56-68, 1997.

[35] Ortiz, F., Simpson, J.R., Pignatiello, J.J., HerediaLangner, A.: A genetic algorithm approach to multiple-response optimization. J. Qual. Technol. Vol. 36, pp. 432-450, 2004.

[36]Lee, D. H., Kim, K.J. and Köksalan, M.: An interactive method to multiresponse surface optimization based on pairwise comparisons. IIE Trans. Vol. 44, pp. 13-26, 2012.

[37] Mangili, I., Lasagni, M., Huang, K., Isayev, A.I.: Modelling and optimization of ultrasonic devulcanization using the response surface methodology based on central composite facecentered design. Chemometr. Intell. Lab. Vol. 144, pp. 1-10, 2015.

[38] Manohar, M., Joseph, J. Selvaraj, T., Sivakumar D.: Application of desirability function and RSM to optimise the multi-objectives while turning Inconel 718 using coated carbide tools, Int. J. Manuf. Technol. Manag. Vol. 27, pp. 218-237, 2013.

[39] Gunaraj, V., Murugan, N.: Prediction and optimization of weld bead volume for the submerged arc process - Part 1.Welding Research Supplement, pp. 286-294, 2000.

[40] Gunaraj, V., Murugan, N.: Prediction and optimization of weld bead volume for the submerged arc process - Part 2.Welding Research Supplement, pp. 331-338, 2000.

[41] Datta, S., Bandyopadhyay, A., Pal. P.: Desirability function approach for solving multi-objective optimization problem in submerged arc welding. Int. J. Manuf. Sci. Prod. Vol. 7, pp. 127-137, 2006.

[42] Aggarwal, A., Singh, H., Kumar.P., Singh, M: Optimization of multiple quality characteristics for CNC turning under cryogenic cutting environment using desirability function. J. Mater. Process. Technol. Vol. 205, pp.42-50, 2008.

[43] Noorossana, R., Zadbood, A., Zandi, F., Noghondarian, K: An interactive artificial neural 
networks approach to multiresponse optimization. Int. J. Adv. Manuf. Technol. Vol. 76, pp. 765-777, 2015.

[44] Myers, R., Montgomery, D., Anderson-Cook, C.: Response Surface Methodology: Process and Product Optimization Using Designed Experiments. 3rd ed., New Jersey: John Wiley \&Sons, 2009.

[45] Tanikic, D., Marinkovic, V.: Modeling and optimization of the surface roughness in the dry turning of the cold rolled alloyed steel using regression analysis. J. Braz. Soc. Mech. Sci. \& Eng., Vol. 34, No 1, pp. 41-48, 2012.

[46] Wolpert, D., Macready, W.: No free lunch theorems for optimization, IEEE Trans. Evol. Comput. Vol. 1, No 1, pp. 67-82, 1997.

НЕКЕ ПРИМЕНЕ НОВЕ ФУНКЦИЈЕ

ПОЖЕЉНОСТИ У СИМУЛТАНОЈ

ВИШЕКРИТЕРИЈУМСКОЈ ОПТИМИЗАЦИЈИ

\section{В. Маринковић}

У оквиру техника вишекритеријумске оптимизације, методологија оптимизације заснована на функцији пожељности једна је од најпопуларнијих и најчешће коришћених методологија код истраживача и практичара из области инжењерства, хемије, технологије и многих других области науке и технике. Бројне функције пожељности уведене су ради побољшања перформанси ове методологије оптимизације. Недавно је предложена нова функција пожељности за вишекритеријумску оптимизацију, која је глатка, континуирана и диференцијабилна и тиме погоднија за примену неких ефикаснијих метода оптимизације на бази градијента. Овај рад процењује перформансе предложене методе на шест примера из праксе. После упоредне анализе резултата, показало се да предложена метода у одређеној мери надмашује остале конкурентне методе оптимизације. 